Excavationless Exterior Foundation Insulation Field Study

T. Schirber, G. Mosiman, and C. Ojczyk NorthernSTAR

September 2014 


\section{NOTICE}

This report was prepared as an account of work sponsored by an agency of the United States government. Neither the United States government nor any agency thereof, nor any of their employees, subcontractors, or affiliated partners makes any warranty, express or implied, or assumes any legal liability or responsibility for the accuracy, completeness, or usefulness of any information, apparatus, product, or process disclosed, or represents that its use would not infringe privately owned rights. Reference herein to any specific commercial product, process, or service by trade name, trademark, manufacturer, or otherwise does not necessarily constitute or imply its endorsement, recommendation, or favoring by the United States government or any agency thereof. The views and opinions of authors expressed herein do not necessarily state or reflect those of the United States government or any agency thereof.

Available electronically at http://www.osti.gov/scitech

Available for a processing fee to U.S. Department of Energy and its contractors, in paper, from:

U.S. Department of Energy

Office of Scientific and Technical Information

P.O. Box 62

Oak Ridge, TN 37831-0062

phone: 865.576 .8401

fax: 865.576.5728

email: mailto:reports@adonis.osti.gov

Available for sale to the public, in paper, from:

U.S. Department of Commerce

National Technical Information Service

5285 Port Royal Road

Springfield, VA 22161

phone: 800.553 .6847

fax: 703.605.6900

email: orders@ntis.fedworld.gov

online ordering: http://www.ntis.gov/ordering.htm 


\title{
Excavationless Exterior Foundation Insulation Field Study
}

\author{
Prepared for: \\ The National Renewable Energy Laboratory \\ On behalf of the U.S. Department of Energy's Building America Program \\ Office of Energy Efficiency and Renewable Energy \\ 15013 Denver West Parkway \\ Golden, CO 80401 \\ NREL Contract No. DE-AC36-08GO28308
}

Prepared by:

T. Schirber, G. Mosiman, C. Ojczyk

NorthernSTAR Building America Partnership

2004 Folwell Avenue

Minneapolis, MN 55108

NREL Technical Monitor: Stacey Rothgeb

Prepared under Subcontract No. KNDJ-0-40338-04

September 2014 
The work presented in this report does not represent performance of any product relative to regulated minimum efficiency requirements.

The laboratory and/or field sites used for this work are not certified rating test facilities. The conditions and methods under which products were characterized for this work differ from standard rating conditions, as described.

Because the methods and conditions differ, the reported results are not comparable to rated product performance and should only be used to estimate performance under the measured conditions. 


\section{Contents}

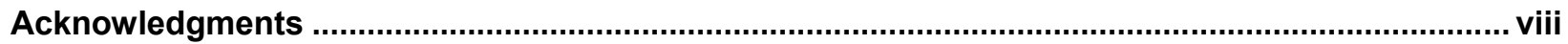

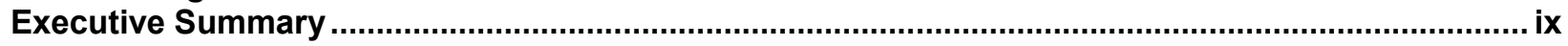

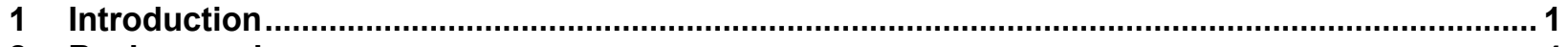

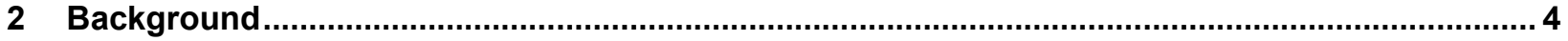

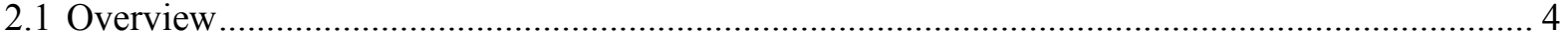

2.2 Difficulty of Insulating Existing Foundation Walls.................................................................. 5

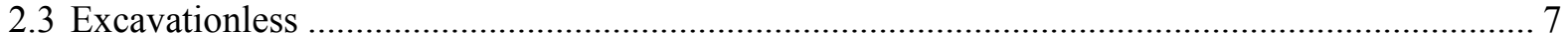

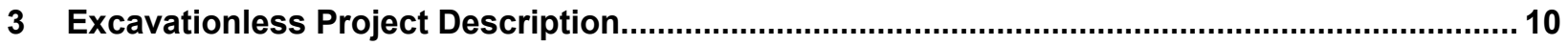

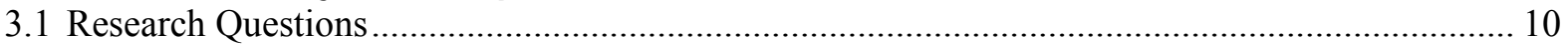

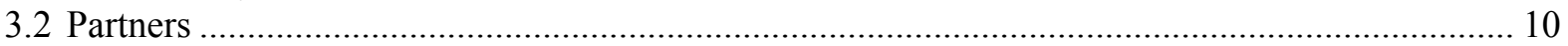

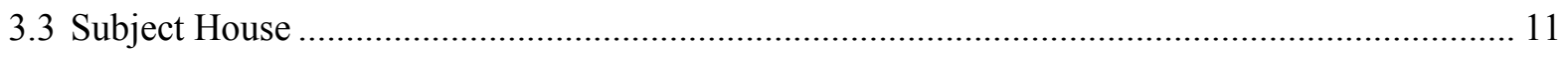

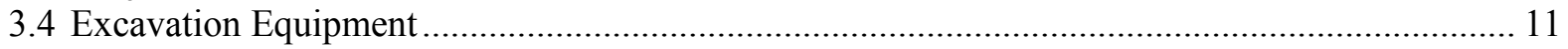

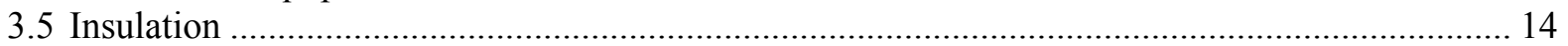

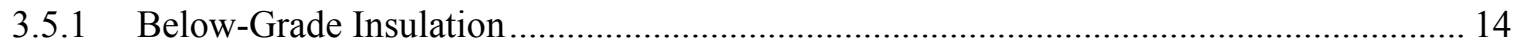

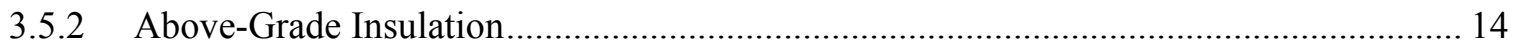

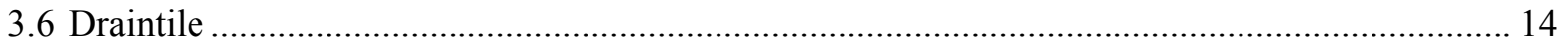

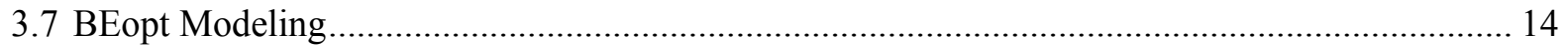

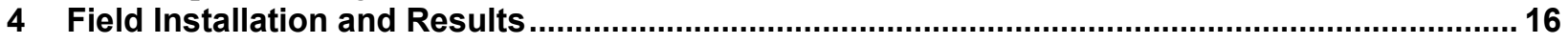

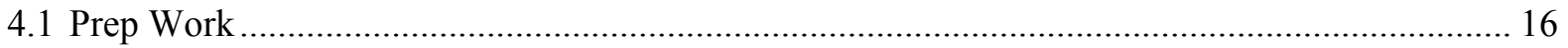

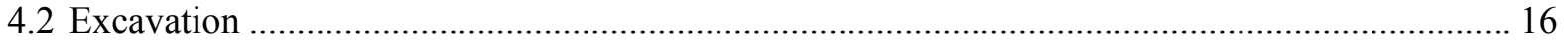

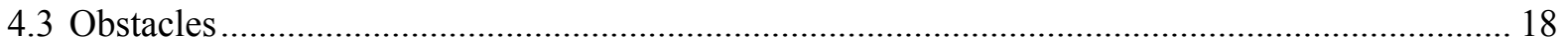

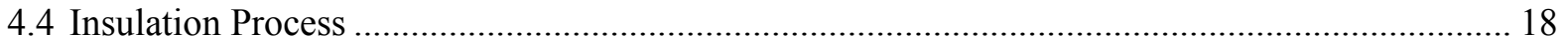

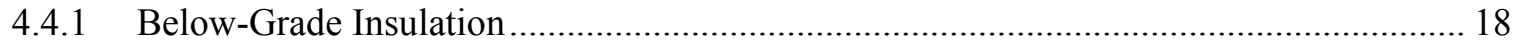

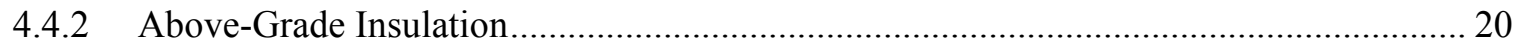

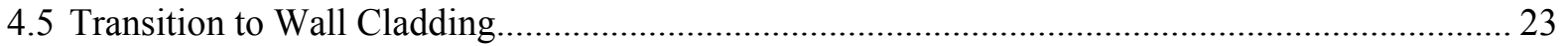

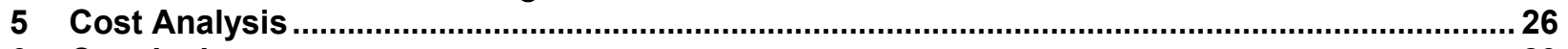

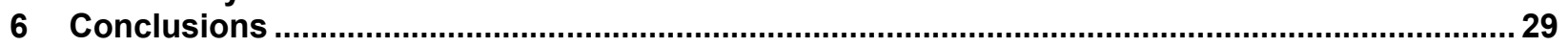

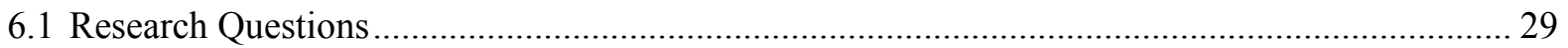

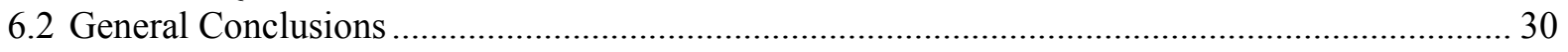

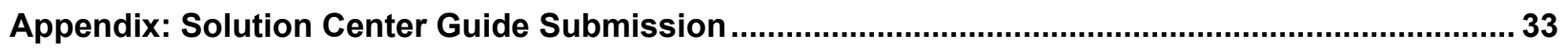




\section{List of Figures}

Figure 1. Thermal and water management strategies of exterior foundation insulation ................... 2

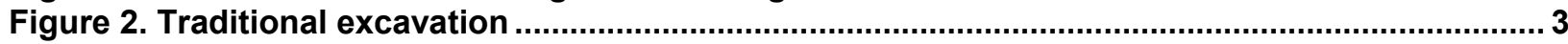

Figure 3. Foundation wall insulation comparisons ........................................................................ 7

Figure 4. Subject house in north Minneapolis prior to renovation .............................................. 11

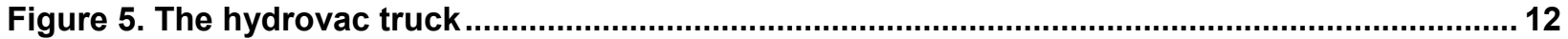

Figure 6. The vacuum hose and truck-mounted pressurized water system.................................. 13

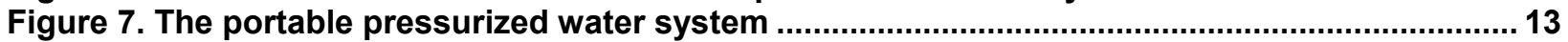

Figure 8. Predicted energy savings from the addition of exterior insulation .................................. 15

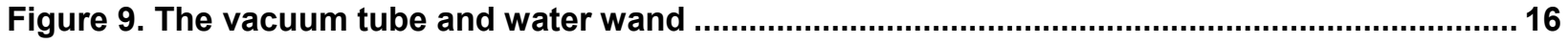

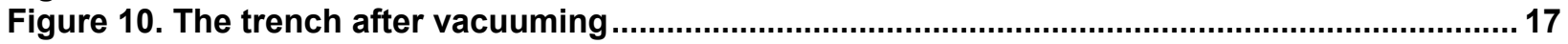

Figure 11. Soil collapse being cleared by vacuum ......................................................................... 17

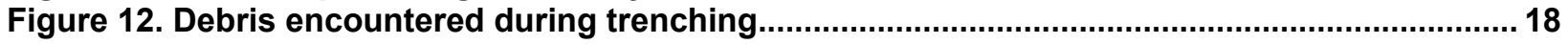

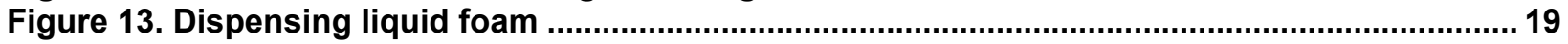

Figure 14. The operator using a 10-in. lift process..................................................................... 19

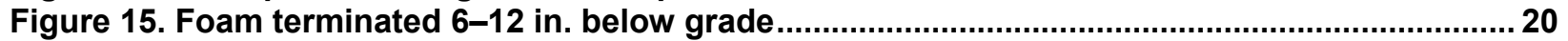

Figure 16. Rigid panel used to contain liquid foam in areas of soil collapse ....................................220

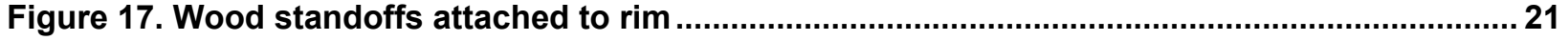

Figure 18. Smooth XPS foam board attached to wood standoffs ............................................... 21

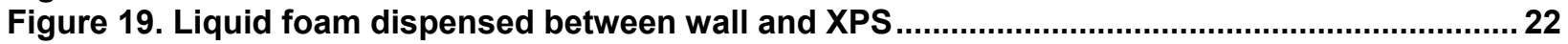

Figure 20. View of above-grade wall after liquid foam was added ................................................ 22

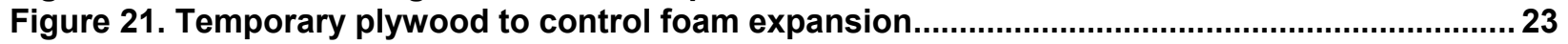

Figure 22. Final result of XPS/liquid foam above grade insulation ................................................ 23

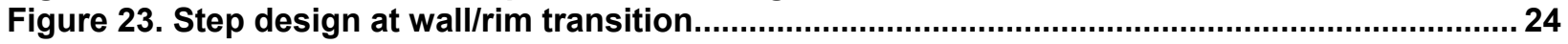

Figure 24. Transition of external wall and foundation insulation ................................................ 25

Unless otherwise noted, all figures were created by NorthernSTAR.

\section{List of Tables}

Table 1. Comparison of Costs: Excavationless Versus Traditional Foundation Retrofit With Backhoe 


\section{Definitions}

AG

BA

BG

BEopt ${ }^{\mathrm{TM}}$

$\mathrm{MBtu} / \mathrm{yr}$

XPS
Above Grade

Building America

Below Grade

Building Energy Optimization Program

Million British Thermal Units per Year

Extruded Polystyrene 


\section{Acknowledgments}

The authors would like to acknowledge the contributions and support of Steve Schirber, Cocoon; Brian Oman, BASF; Tony Traxler, American Environmental; Urban Homeworks; Pat Huelman, University of Minnesota, for their expertise and roles as advisors to the project. 


\section{Executive Summary}

Building science research supports installing exterior (soil side) foundation insulation as the optimal method to enhance the hygrothermal performance of new homes. With exterior foundation insulation, water management strategies are maximized while insulating the basement space and ensuring a more even temperature at the foundation wall. Controlling for bulk water, vapor, and wall temperature differential reduces the risk of rot and mold formation to insulation and building materials, thereby improving opportunities for structural integrity, indoor air quality, comfort, and energy efficiency.

However, such an approach can be very costly and disruptive when applied to an existing home, requiring deep excavation around the entire house. In addition, removed soil must be stockpiled close to the excavation, increasing the size of the project area and attendant landscape impact. A uniform and continuous exterior excavation around the perimeters of existing homes is further complicated by barriers and constructed elements. These include items such as attached garages, porches, decks, cantilevered floors, concrete steps and stoops, and mature plantings. These costs and impacts are generally sufficient to prevent most homeowners and contractors from pursuing an exterior approach.

The NorthernSTAR Building America Partnership team implemented an innovative, minimally invasive foundation insulation upgrade technique on an existing home. The approach consisted of using hydrovac excavation technology combined with a liquid insulating foam. The team was able to excavate a continuous 4-in. wide $\times 4-5$-ft deep trench around the entire house, 128 linear $\mathrm{ft}$, except for one small part under the stoop that was obstructed with concrete debris. The combination pressure washer and vacuum extraction technology also enabled the elimination of large trenches and soil stockpiles normally produced by backhoe excavation. It accommodated obstructions to remain in place or be minimally modified. The resulting trench was filled with liquid insulating foam, which also served as a water-control layer of the assembly. The insulation was brought above grade using a liquid foam/rigid foam hybrid system and terminated at the top of the rim joist.

Two houses were originally selected for this field study. One was not ready for retrofit at the time of study and had to be eliminated. The collaborative nature of the one field installation, however, enabled the team to advance the methodology as the work progressed. Improvements to the method of installation and reduction of costs were developed on site. Cost savings over the traditional excavation process ranged from $23 \%$ to $50 \%$. The excavationless process could result in even greater savings since replacement of building structures, exterior features, utility meters, and landscaping would be minimal or nonexistent in an excavationless process. 


\section{Introduction}

The growing cultural focus on energy efficiency and homeowner desire to expand living space to the basement, create urgency for good, usable information on best practice strategies for insulation systems, especially for existing homes in cold climates. The principal risks to basement spaces that are surrounded by soil and experience both above-grade (AG) and belowgrade (BG) conditions concern hygrothermal durability. Foundation walls almost always experience variations in temperature and drying potential from the top (AG) to the footing (BG), from season to season, and from wall to wall depending on solar orientation and design. Lack of waterproofing, capillary breaks, and drainage at the footing provide further risk for increased moisture stress resulting from bulk water intrusion or capillary wicking.

While the soil prevents a foundation wall from drying to the exterior, interior insulation and the presence of vapor impermeable materials can reduce the opportunity for the foundation wall to dry to the interior, creating continually wet insulation and building materials. Temperature difference from top of the wall to the bottom may also exacerbate the movement of water vapor towards the sill and rim, especially in hollow core masonry block. Moisture accumulation may lead to deterioration and rot of the building structure components, loss of energy efficiency and occupant comfort, as well as the opportunity for mold growth and resultant poor indoor environmental quality.

There is a growing body of research and field experience indicating that applying insulation to the exterior of the foundation during new home construction and implementing proper bulk water management strategies greatly reduces the risks related to water/vapor flow and foundation wall temperature differential. (Mosiman et al. 2012) The results are indicating a more comfortable, durable basement environment along with energy efficiency gains. The following illustration (Figure 1) highlights the key elements for insulation and water management on the exterior side of the foundation wall. 


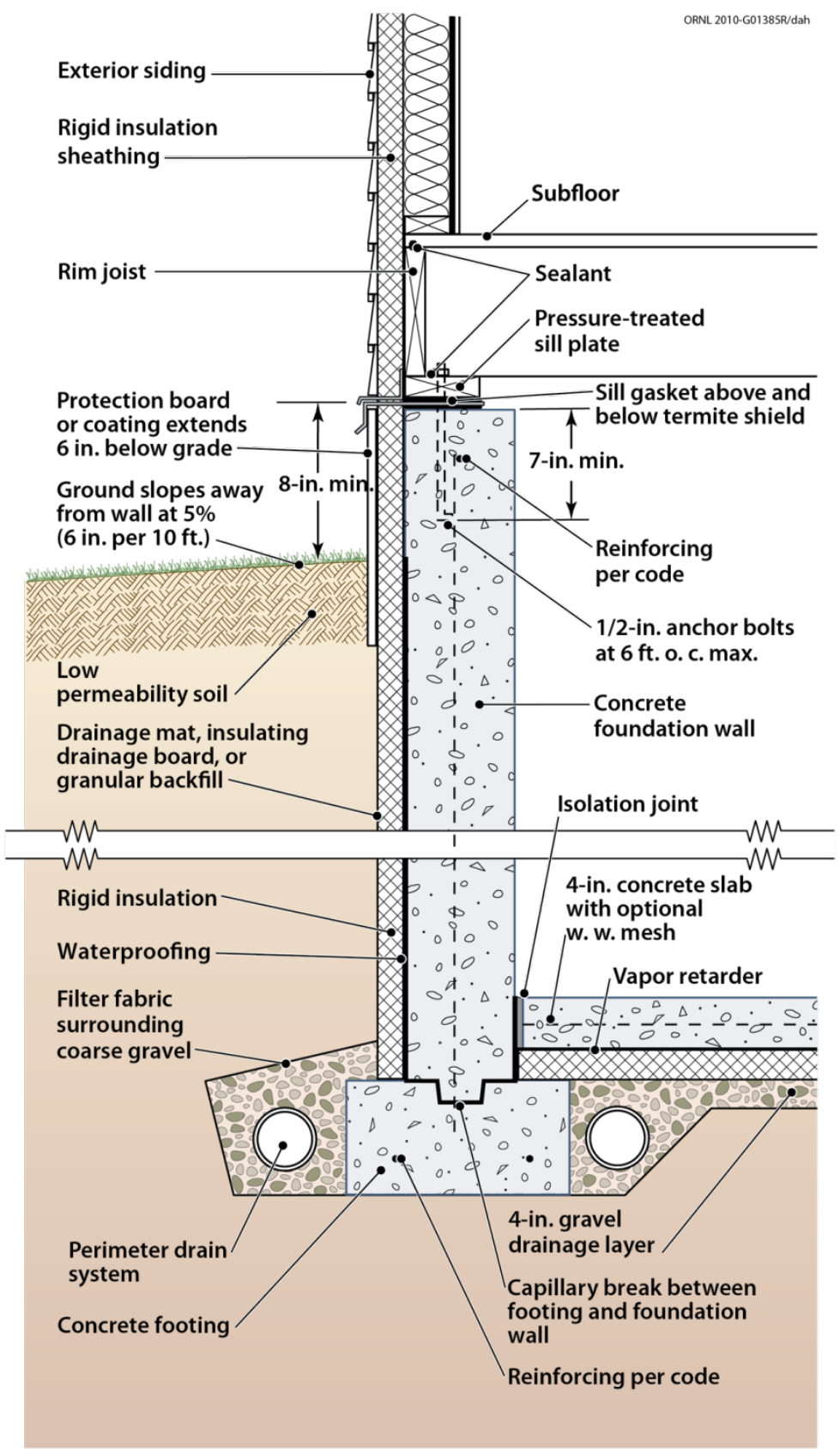

Figure 1. Thermal and water management strategies of exterior foundation insulation

(Adapted from: Carmody et al. 2005)

Although it is relatively simple to employ this exterior insulation system in new construction prior to backfilling, there are significant barriers to its use in upgrading existing homes. Applying insulation to the exterior of existing homes is costly and destructive due to the need to excavate a large trench using a backhoe to facilitate application of insulation and water proofing materials to the foundation wall (Figure 2). Gaining access to the foundation walls may also mean the removal and replacement of stoops, patios, porches, and landscaping with significant cost and coordination to attend to underground utilities. 


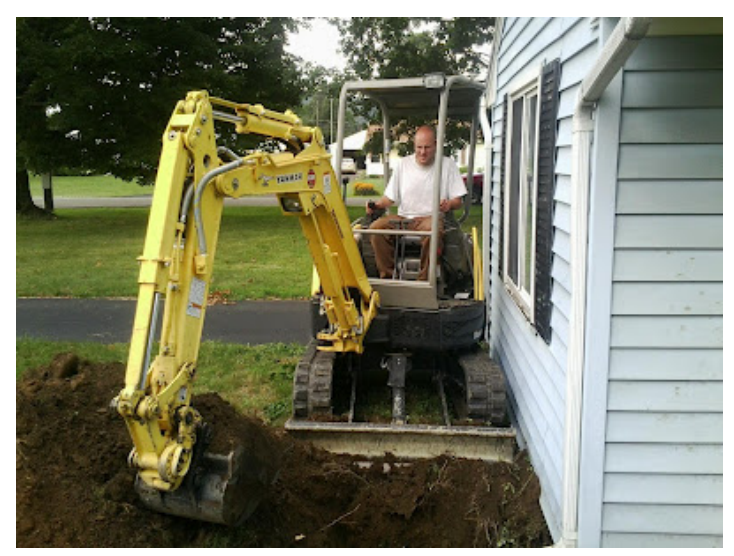

Figure 2. Traditional excavation

In a previous Building America (BA) report (Mosiman et al. 2012), the NorthernSTAR Building America Team identified a new, minimally invasive excavation and insulation technique for existing home foundation, referred to as excavationless. It is based on existing hydrovac and airvac technology that is capable of precisely excavating a trench directly adjacent to the foundation wall. The team also identified three pourable materials capable of curing in place to serve as a moisture-resistant, insulating material.

In this study, the team sought to test the excavationless process using a combination of the hydrovac technology and a liquid foam insulation product in the field to answer some basic questions about the new approach. Although the technology and materials identified in the initial exploratory study are mature, the combination has not been tried. A field application would provide a sense of the general feasibility of the proposed excavation and exterior foundation methodology for existing homes. Lessons learned from the study will help inform future research for the development of an exterior-side, foundation insulation system for existing homes that could be deployed by the industry while avoiding many of the moisture-related issues common to many interior insulation strategies in common use. 


\section{Background}

\subsection{Overview}

In the upper Midwest, where annual frost depths of 3-6 ft are not uncommon, basements are a common occurrence in older housing stock. With foundation walls for homes typically extending 4 or more $\mathrm{ft} \mathrm{BG} \mathrm{(a} \mathrm{structural} \mathrm{code} \mathrm{requirement} \mathrm{to} \mathrm{protect} \mathrm{the} \mathrm{foundation} \mathrm{from} \mathrm{frost} \mathrm{heave),} \mathrm{the}$ construction of a full basement was and is a matter of practicality. Basements often contain mechanical equipment and plumbing systems, which are at risk if the temperature of the basement falls below freezing. Therefore, whether occupied or not, basement spaces in very cold climates are usually functionally inside the thermal envelope and must remain so in order to protect the systems located within them. Despite the fact that most basements in homes are heated either directly or indirectly, insulating basement walls or slabs was not common practice until energy code requirements mandated this practice. Thus, most basements in homes built before 1993 (the time when the first model energy code began to be adopted in the United States) are uninsulated.

Heat loss through uninsulated basement walls is a significant energy penalty in heating climates. As more and more attention is focused nationwide on improving the energy efficiency of the existing housing stock, it becomes imperative that "a home with a basement must have basement insulation to be called 'energy efficient" (Lstiburek and Yost 2002).

With uninsulated, conditioned basements a common occurrence in cold climate regions, it follows that millions of homes could potentially benefit from basement insulation retrofit measures including:

- Homes with finished basements

- Homes with inaccessible basement walls

- Homes with expensive landscaping

- Homes with crawlspaces

- Homes that need waterproofing

- Homes, townhomes, and apartment buildings with slab foundations

- Buildings that need foundation repair

- Homes that need insulation under porches and sidewalks.

Based on the 2011 American Housing Survey (U.S. Census 2011), there are an estimated 81 million single-unit homes in the United States. More than 79 million of those units have a basement under all or part of the structure, a crawlspace, or were built on a concrete slab. In the cold climate states of the Northeast and Midwest there are 32 million units that could potentially benefit from exterior insulation.

An affordable, durable, scalable method for insulating basement foundation walls does not currently exist in practice. If such a method could be identified it would become a valuable part of the integrated approach utilized in the BA program's adoption and implementation strategies 
aimed at climate-specific solutions that result in 50\% home energy reduction while addressing occupant health and durability.

\subsection{Difficulty of Insulating Existing Foundation Walls}

"There are only three ways to insulate a basement wall," Lstiburek and Yost (2002) stated in a research report: "on the interior, on the exterior, or in the middle." They further noted that of the three approaches, the most common was to insulate on the interior, and that the reason for this is mainly about cost. Applying insulation to the exterior of the foundation and implementing proper bulk water management strategies both $\mathrm{AG}$ and BG, however, reduces the risks of building damage related to water and vapor flows and foundation wall temperature differential.

In existing basements, it could be argued there are only two ways to insulate a basement wall: from the interior or from the exterior. It is rare that an existing basement wall is constructed in such a way as to facilitate the addition of insulation to the middle of the wall. It is possible to insulate an existing wall from both the interior and the exterior but practicality would suggest that such an approach would also be rare since insulating both the interior and exterior of an existing basement wall would be the most disruptive approach and would not be cost effective. When an existing basement is insulated, it is most commonly done so from the interior, often in conjunction with an attempt to "finish" the basement for the occupants' living use. The practice of an interior insulation upgrade makes sense when the factors being considered focus on initial cost of the upgrade, disruption to the existing structure, and the interest in providing living space in the basement. However, the practice introduces risks to the building and its occupants that suggest that this common practice is far from "best practice."

An unfinished, uninsulated, largely unoccupied basement typically provides conditions allowing the foundation walls (and floor slab) the ability to dry to the inside. In addition, an unfinished basement by definition isn't filled with building materials (wood studs or furring, insulation, gypsum drywall, wood paneling) that invite and support mold growth when interior moisture is present. The practice of finishing and insulating a basement interior can be risky business and the popularity of insulating basements to the inside has grown along with the popularity of "finishing" basements, despite a clear body of research that advises against this practice.

Fugler (2002) reported in detail on the occupant health risks and building durability risks associated with finishing or adding insulation to the interior of a basement with moisture problems. Those risks include toxigenic or pathogenic mold growth potentially harmful to occupants (especially children). It was estimated that in Canada $20 \%-50 \%$ of basements visited had moisture problems. Fugler advised that the interior basement walls should be left unfinished in a cold climate because, among other things, "there is too much risk in disturbing the moisture and temperature environment that has maintained this foundation for decades. Accumulated moisture in the foundation wall could not escape and dry to the inside faster than it could accumulate within the new interior finishes, where mold and mildew now had a chance to flourish. However, Fugler concludes the report noting that "if the homeowners are also prepared to add exterior drainage and insulation, interior finishing would pose no problem," meaning that the risk could be mitigated by preventing moisture intrusion into the wall and managing bulk water with an exterior upgrade. 
Lstiburek and Yost (2002) also concluded that "continued use of these approaches by the home building industry will likely lead to a disaster of unprecedented proportions and may result in the construction of energy efficient homes being set back a generation." These 2002 reports, published by recognized building science experts in both Canada and the United States, identified and described the inherent risks in a basement retrofit approach that is still in common practice today. Little has changed in the materials and methods still in use and it appears that Lstiburek and Yost's warning of disaster wasn't off the mark. Mold and mildew in homes have become such a pronounced and expensive occurrence that many property and casualty insurance policies no longer cover damage from mold. In addition, while a causal link between mold in interior environments and respiratory illnesses such as asthma, an associative link has been widely accepted and reported on in journals, articles, websites, and books.

The research by the National Research Council of Canada (Swinton et al. 1999) identified the benefits of an exterior retrofit approach using the conventional method of full depth excavation with a trench wide enough to accommodate the installation of drain tile, waterproof material and insulation, but it does not address costs or other barriers to this approach. The National Research Council of Canada research was conducted on an International Residential Code test house, so occupants were neither disrupted nor financially responsible. In addition, this test house did not appear to have exterior physical barriers present that are common in many existing homes.

In the previous NorthernSTAR report (Mosiman et al. 2012), two recently completed projects in northern Minnesota provide examples and current cost information about the "conventional" approach to exterior foundation insulation retrofits. A similar backhoe insulation strategy was employed on the two foundations. In each case, the walls were waterproofed, draintile was added or remained, and extruded polystyrene (XPS) rigid foam insulation was mechanically fastened to the existing foundation wall, from top of foundation wall to top of footing. The final costs for this type of approach was within the cost range estimated for current advanced approaches to deep energy retrofits at $\$ 7-\$ 15 / \mathrm{ft}^{2}$ (Mosiman et al. 2012).

Figure 3 illustrates the negative impact of insulating an existing foundation wall from the interior compared to the benefits of applying it to the exterior. Noted, however, is the cost to upgrade an existing wall using conventional backhoe methods that often prevents homeowners from pursuing this option. 


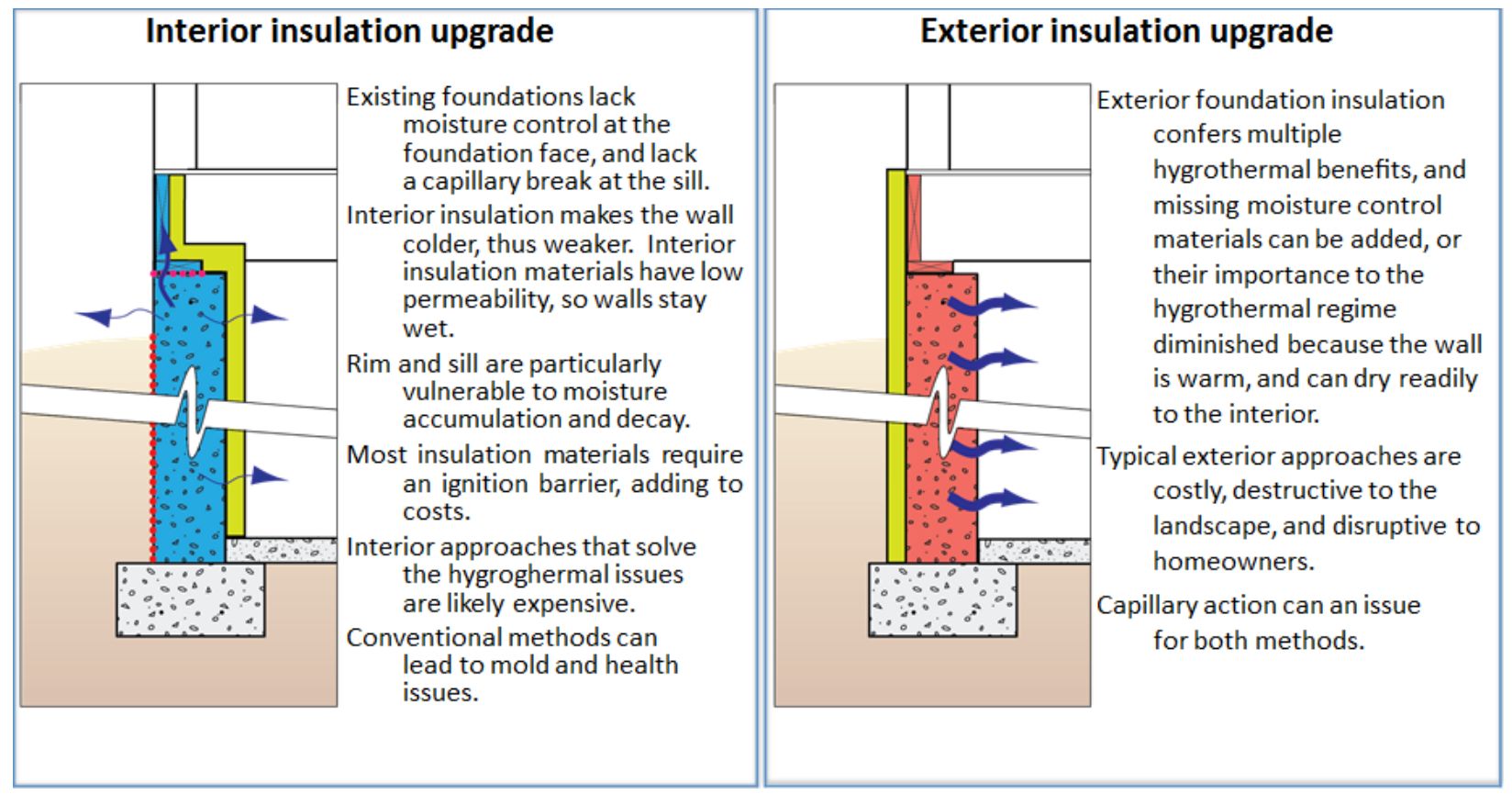

Figure 3. Foundation wall insulation comparisons

The previous BA report (Mosiman et al. 2012) also presented results from a Neighborhood Obstruction Analysis of five Minneapolis, Minnesota neighborhoods to try to quantify the type and occurrence of obstructions that would interfere with full access to the foundation walls. Most of the time $75 \%$ or more of the foundation perimeter appeared to be accessible to some form of excavation without removal of the obstacle. The single most frequently occurring obstacle is the presence of a concrete stoop at the front entry. Since this element often sits on a foundation that extends several feet or more into the ground for frost protection, removing and replacing this obstacle would not be desirable. Additional frequently occurring obstacles included adjacent but not abutting sidewalks, plantings and the existence of a projecting bay without a foundation. These obstacles make conventional excavation methods unsuitable.

\subsection{Excavationless}

The "excavationless" process proposed by the Team in the previous report (Mosiman et al. 2012) presents a minimally invasive foundation insulation retrofit technique in existing homes that combines two existing processes in a new format. The trenching technology (hydrovac or airvac) uses pressurized water or compressed air to loosen soil, while simultaneously applying suction from a truck- or trailer-mounted vacuum to remove the spoil. This technology is currently used for a wide variety of excavation processes, including exposing existing foundations. The method was initially developed to expose buried utilities for inspection or location purposes, so it is unlikely to cause damage to utility lines that are encountered in a foundation wall excavation process. The narrow width of the cut minimizes damage to the area around the foundation while the long, flexible vacuum hose can "tunnel" under obstacles.

In addition, the previous work identified three liquid materials that cure in place as a moistureresistant, insulating material that may be appropriate in this application: cellular concrete, perlite 
aggregate concrete, and liquid polyurethane foam. All three materials are in current use in BG applications. The trench is filled with the liquid insulating material, which when cured forms the insulating (and potentially water-control) layer around the foundation.

The benefits of insulating from the exterior using this excavationless approach could include:

- Reduced whole-house energy use

- A foundation wall that is warm on the interior side for improved comfort

- Improved airtightness of the house

- A liquid insulation product that tends to be forgiving of existing envelope defects

- Vacuum excavation method that greatly reduces landscape impacts

- Many landscape features (walks, stoops, decks, etc.) that would be removed for traditional excavation can be tunneled under

- A quick process estimated at one to two days for a simple home

- Opportunities to add interior and exterior draintile with the hydrovac equipment

- Using the hydrovac equipment to underpin a foundation to lower the floor

- Potential waterproofing and reduction in bulk water intrusion from the cured insulation

- Costs likely to be lower than backhoe methods of exterior insulation and landscape repair.

There are possible tradeoffs to doing a minimally invasive, excavationless foundation retrofit approach versus a traditional interior or exterior foundation wall retrofit. Those include:

- Method does not address moisture loading from sources such as capillarity from the footing or through the slab.

- More expensive than typical interior insulation methods.

- Long-term thermal properties are not known; potential for moisture accumulation within pore spaces may cause thermal degradation.

- Large obstructions (patio slabs, sidewalks that abut the foundation) will need to be sawcut to the trench width, or removed and replaced.

- Extent of waterproofing ability, and durability of that solution, is not well characterized.

- Creating an undercut pocket at the bottom of the trench to properly install draintile appears possible given the flexibility of the hydrovac equipment but has not been tested.

Further study regarding the ability to add draintile to the narrow trench created by the hydrovac system has further merit for study: Excavationless could address what could be considered missed opportunities. Homes that are near a lake or high water table often experience active water issues. A local excavation contractor that uses a conventional backhoe excavator was interviewed for this project. A significant part of his business involves trenching around the 
foundations of luxury homes situated near lakes to install waterproofing and draintile. He stated that the cost of the process, which includes his services as well as the efforts to restore landscaping, is very high. Homeowners pursue his services to solve their water intrusion problems.

When asked what kind of insulation the contractor used after the typical application of a peel and stick waterproofing membrane, he responded, "What insulation?" The contractor further explained he was hired to excavate, install the waterproofing membrane, and then backfill the trench. He was never asked to apply insulation. It is not known how many opportunities to address insulation alongside water management could be addressed with excavationless. 


\section{Excavationless Project Description}

The primary purpose of this project was to perform a complete excavationless process as proposed in the previous BA report (Mosiman et al. 2012) using the hydrovac technology combined with the liquid insulation. Field installation would provide opportunities to further understand the proposed benefits and tradeoffs while understanding how best to combine the systems in the field. The field process would also help develop solutions to insulation and aesthetic design transitions at the AG wall/rim/wall cladding. The field installation would help us learn what issues might occur BG with a narrow trench such as soils caving in, rocks, metal scrap, and other previous construction debris that could hinder the excavation process. A field study would also provide insight into material cost, time cost, and potential for damage in the yard that will need to be repaired.

\subsection{Research Questions}

The following research questions served as a guide:

- What is the impact of the hydrovac equipment on the landscaping?

- What issues result when digging a narrow trench around the foundation?

- How are obstacles such as sidewalks and stoops handled?

- How is insulation handled AG in order to minimize costs and maximize benefits of the system?

- How are transition details handled from AG insulation to wall?

- What are the costs associated with installation of the system?

\subsection{Partners}

Along with NorthernSTAR team members, the following group helped develop the means and methods of the excavationless both in planning and on site. They will continue to work with us to ensure a quality product is developed and can be replicated at a significant scale.

- Urban Homeworks: Is a faith-based, nonprofit that develops housing and community development programs in neighborhoods across Minneapolis and St. Paul. Along with creating housing opportunities, it has facilitated construction training, and worked with 17,000 volunteers to produce hundreds of units of housing.

- Cocoon: Is an insulation, home performance testing, and radon mitigation contractor. Steve Schirber, general manager and principal, is a Building Performance Institutecertified envelope specialist and building analyst. Cocoon's work is primarily conducted in Minnesota.

- BASF Corporation: Is a global chemical company. Brian Oman has been a technical sales representative in the Minnesota region with BASF since 2007. He provides training and technical assistance with spray polyurethane foam insulation.

- American Environmental, LLC: Provides industrial vacuum and hydro excavation services. Tony Traxler is the business owner. 


\subsection{Subject House}

The subject home was built in 1906 on a corner lot in the northern section of Minneapolis, Minnesota. This vacant and boarded home was purchased by Urban Homeworks in order to be rehabilitated and sold to a low-income family. It was unoccupied at the time with the intent that it be completely gutted for energy and interior/exterior improvements.

Figure 4 represent the home prior to the upgrades. The footprint of the home is $38 \mathrm{ft} \times 26 \mathrm{ft}$. The foundation is made of stone. Prior to the excavationless process and as part of the planned improvements, the general contractor, Urban Homeworks, removed all the exterior siding, the garage with footings, the back porch with footings, and bump out room with footings. The front entry had a concrete stoop.

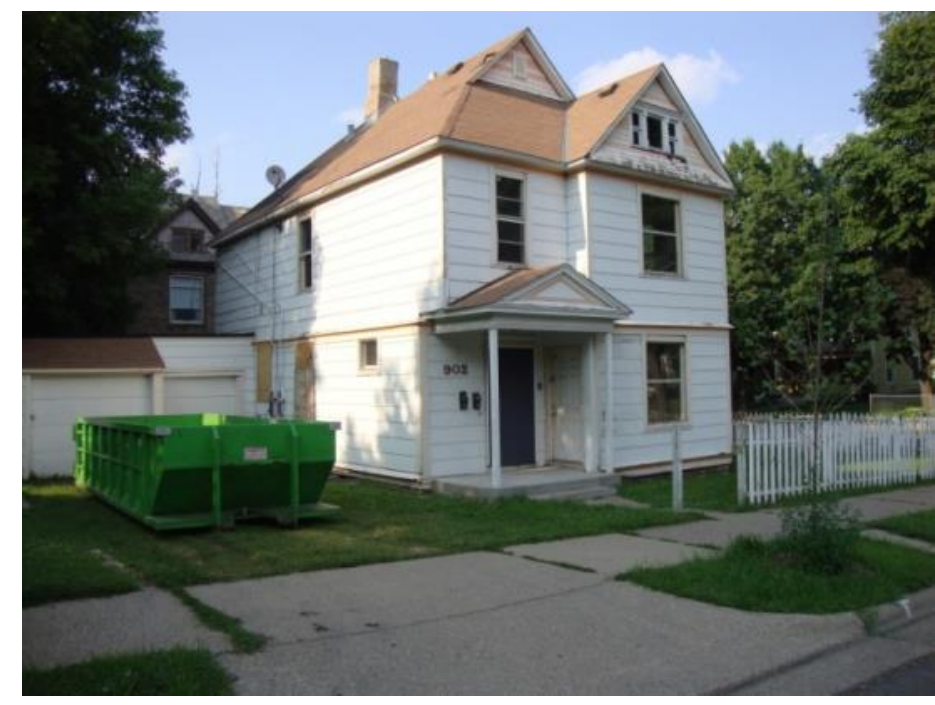

Figure 4. Subject house in north Minneapolis prior to renovation

\subsection{Excavation Equipment}

The key to the success of this approach was the vacuum excavation truck, Figure 5, also called suction excavator that has been around for decades. These trucks, equipped with high pressure water, pressurized air, or both come in various sizes to perform large or small excavations. For smaller jobs, they also come mounted on a trailer, pulled by a small truck. They are used for locating utilities and digging in places where a large backhoe might cause harm to the underground piping or wires. They are also used to clean out culverts and other underground service areas. 


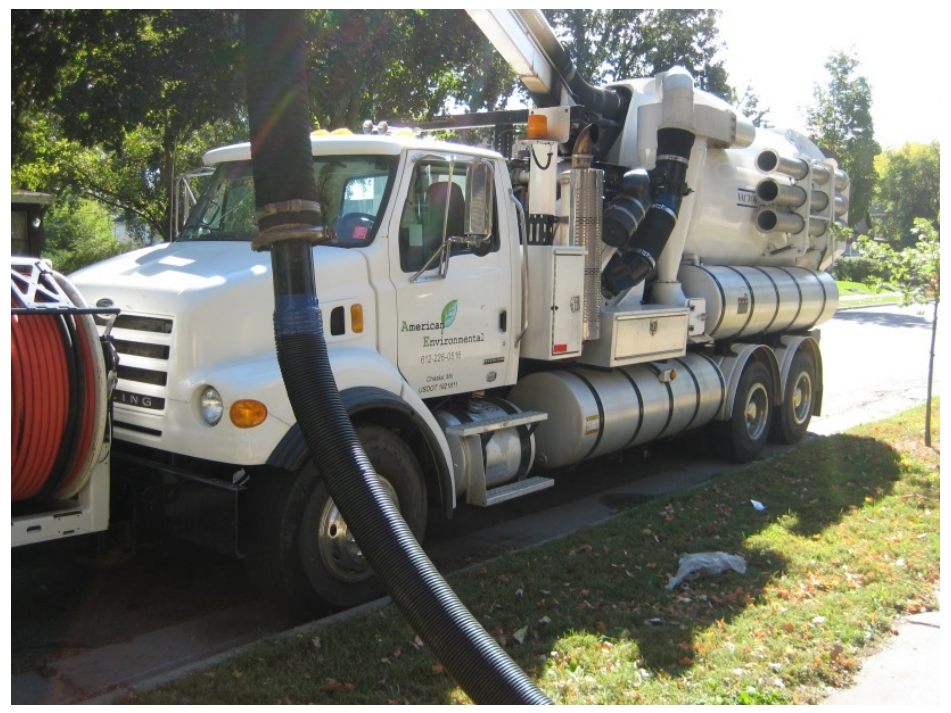

Figure 5. The hydrovac truck

The truck used by the excavation contractor, American Environmental, had two diesel engines. The main engine, which also powers the truck on the road, helped generate power for the mechanical systems. The second engine ran the large fan that creates suction for soil removal. The unit also had:

- 1000 gallon water tank capacity

- 12 cubic yard debris body

- Water pressures up to 14 gpm@3000 psi

- Airflow of $5800 \mathrm{cfm}$ capable of removing debris at $220 \mathrm{mph}$.

- Rear-mounted 8-ft telescoping boom capable of $19-27-\mathrm{ft}$ reach, $335^{\circ}$ rotation, $45^{\circ}$ upward, and $25^{\circ}$ downward pivot

- Debris collector body features ejector plate unloading with raise/tilt capability

- 450,000 Btu water heater for excavation of frozen soils.

The unit can roll out up to $400 \mathrm{ft}$ of 8 -in. hose to meet the availability of space and access. In this case, the home is located on the corner lot of the block so minimal hose length was needed. The truck could be positioned in two locations if needed.

The unit has its own onboard pressurized water system that can operate at 14 gpm (Figure 6). 


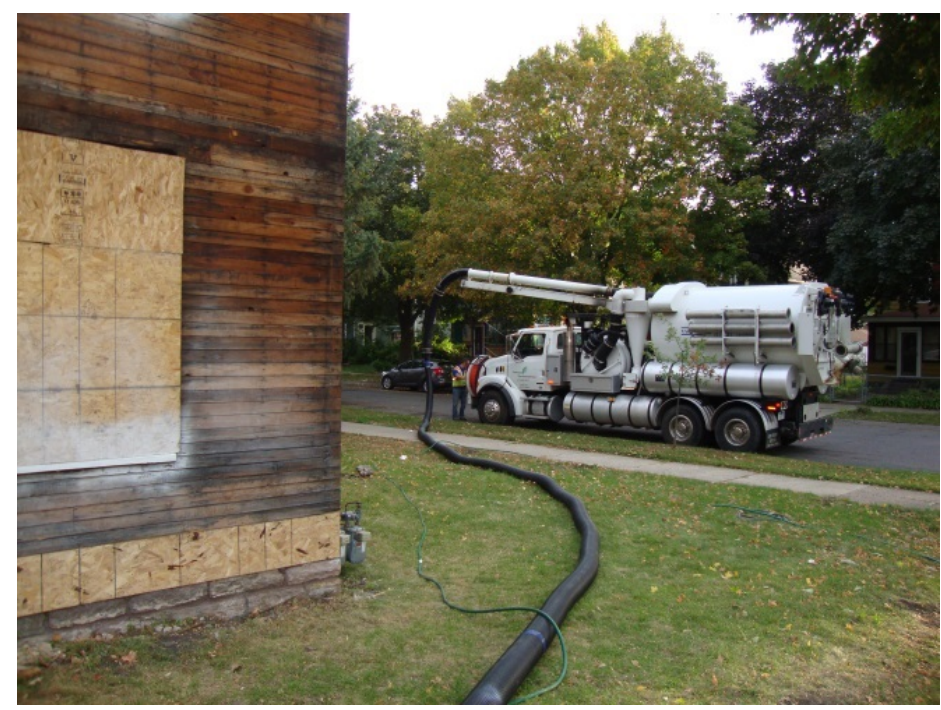

Figure 6. The vacuum hose and truck-mounted pressurized water system

The hydrovac operator also brought a secondary portable pressure washer, shown in Figure 7. It also operates at 3,000 psi but uses only $2.7 \mathrm{gpm}$ and can be operated with a garden hose. The two soil removal systems were a benefit to the project. The operator could switch to the smaller pressure washer when appropriate. Once a truck tank is full, work at the job site shuts down until the load is taken to a dump site to empty. The smaller pressure washer minimized the amount of water and soil sent to the tank, thus extending the time before filling a truck load and stopping work to empty the tank. In this project we were able to work the entire day before the tank was filled and needed to be emptied.

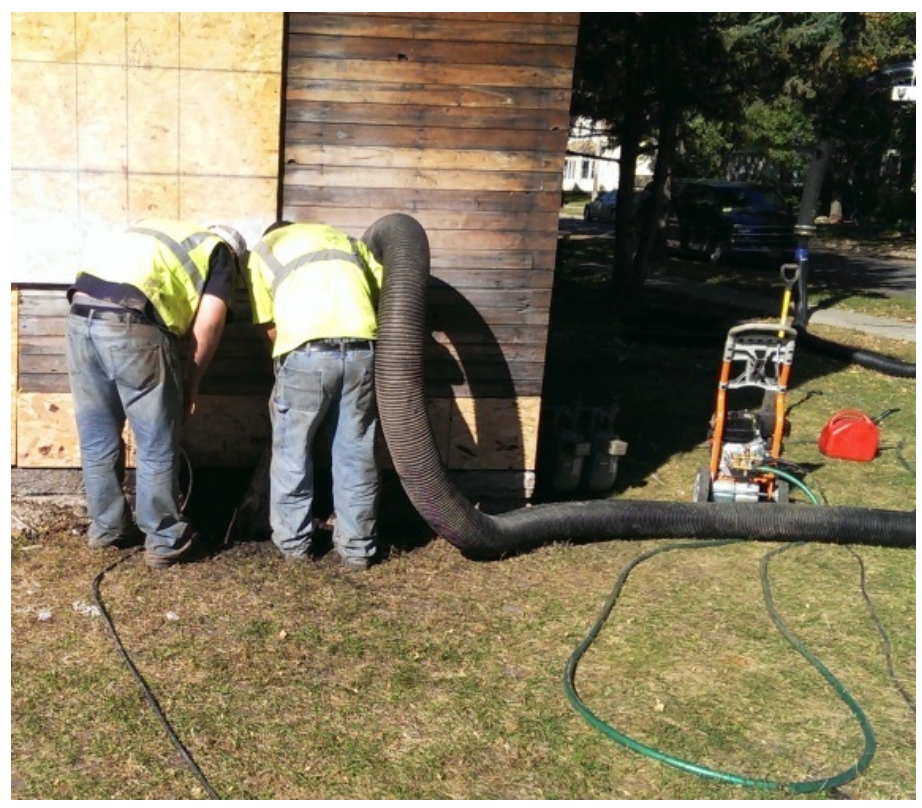

Figure 7. The portable pressurized water system 
The pressurized water "wand" has several nozzle shapes. One is round like a pencil, and the other is flat, spreading out like a spade shovel. General digging was done with the spade shape and tunneling was aided by the pencil shape. To initiate digging, the pressurized wand was pointed at the soil, which immediately became loose and broke apart. The vacuum tube was placed next to the water wand and immediately removed the loose soil.

\subsection{Insulation}

\subsubsection{Below-Grade Insulation}

The foam used in this excavationless process was developed by BASF chemists specifically for this project. Our specifications required a liquid foam that could be used BG and in contact with soils and moisture. BASF chose cast-in-place, naturally hydrophobic closed cell polyurethane foam, R-5/in., where $90 \%$ of the foam's mass is comprised of individual cells which will not allow for the transfer of moisture from one cell to another. In addition, a specialized formulation was developed for this specific application utilizing materials that would further reduce the chance for water intrusion and further increase its hydrophobicity while also enabling the foam to aggressively adhere to smooth or rough surfaces.

Using liquid foam would be beneficial in the following ways:

- It would replace all the soil that was removed requiring very little backfill.

- It would conform easily to the space BG and obstacles such as tree roots, pipes, and stones.

- It would conform and adhere to the rough stone foundation.

- It could act as insulation and water control layer.

\subsubsection{Above-Grade Insulation}

A hybrid rigid/liquid foam combination was used from 6-12 in. BG to the top of rim. Rigid XPS was fastened to the rim using wood standoffs. The gap would provide space for the liquid foam to expand against rough, imperfect surfaces. The XPS would provide a plumb surface for exterior cladding or parge layer.

\subsection{Draintile}

The subject home had no active water issues. The costs that would be required for creating the appropriate trench and adding draintile were allocated to other parts of the whole house retrofit.

\subsection{BEopt Modeling}

The NorthernSTAR team used the Building Energy Optimization (BEopt ${ }^{\mathrm{TM}}$ ) software version 2.2.0.0 to better understand the potential reduction in annual energy use that could result from the addition of exterior insulation. Actual energy testing on the study home was outside the scope of work, as it would not be rehabilitated until after the excavationless process and the next occupant and their willingness to participate in an energy study was unknown.

The BEopt software was used to simulate the energy performance of an existing reference home in Minneapolis, Minnesota. The NorthernSTAR team developed the reference home, named

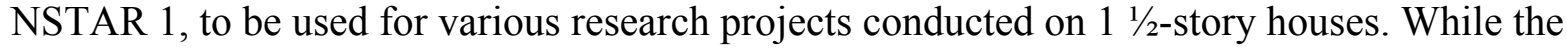


excavationless test home is two-story, it had been gutted prior to start of the project. There were no existing building parameters to guide the BEopt inputs. Using the NSTAR 1 reference home would provide some context for the results as NSTAR 1was created to reflect housing typical to the Minneapolis area. The 28 - $\mathrm{ft} \times 36$ - $\mathrm{ft}$ foundation with full basement, first floor, and attic living space yield 2,664 $\mathrm{ft}^{2}$ of conditioned living space. Some of the BEopt defaults were changed to reflect what is typically seen in Minneapolis. This included R-7 insulation in walls and kneewalls, R-7 in the finished roof, R-25 attic floor insulation in the kneewall area, and doublepane windows with nonmetal frames.

The column on the left in Figure 8 represents the average source energy use per year (MMBtu/yr) of the existing home. The column on the right represents the impact on source energy use per year after the installation of R-15 exterior foundation insulation via the excavationless process. The computer simulation indicates an $8 \%$ reduction in whole-house energy use with the majority of the savings coming from a reduction in heating energy.

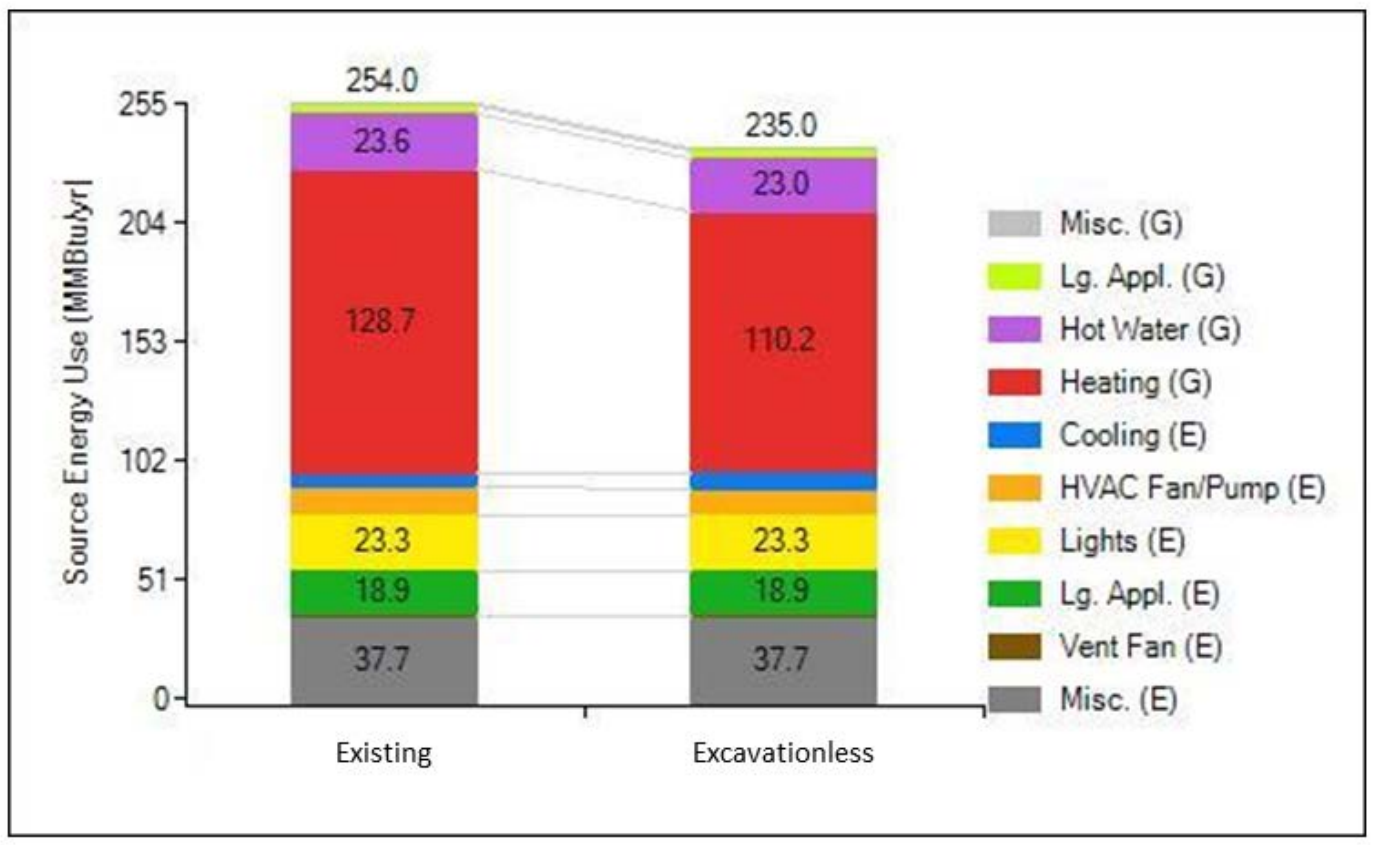

Figure 8. Predicted energy savings from the addition of exterior insulation

The $8 \%$ energy savings, however, may underrepresent the reduction in energy use due to limitations of the BEopt program that constrains the ability to model rim and AG basement heat flows: Only the BG impacts are measured. Greater energy use reductions than demonstrated may be experienced in a home where the rim and AG foundation wall are insulated, such as in the excavationless field study house. 


\section{Field Installation and Results}

\subsection{Prep Work}

The subject house was vacant at the time of purchase and slated for complete exterior/interior rehabilitation. After the contractor removed the wall cladding, improvements were made to the rim using new oriented strand board as filler for missing sheathing. Window wells were removed. Windows and frames were removed and openings were filled with a backing of rigid foam board flush with the foundation wall.

\subsection{Excavation}

The standard tube in the hydrovac is 8 in. diameter. Our desired trench width was meant to be 4 in. wide. To accommodate the difference between equipment and desired trench width, the vacuum tube and water wand were placed in the middle of a section of wall and made to "dig" downward to the desired depth. In this project it was determined that excavation depth would be approximately $4 \mathrm{ft}, 6 \mathrm{in}$. BG yielding a total insulation height of $6 \mathrm{ft}$. The wand was moved away from the vacuum tube along the wall cutting as narrow a trench as possible. Figure 9 shows how the wand pushed the sludge toward the vacuum tube as it cut through the soil. It can push water 8-10 linear $\mathrm{ft}$ before the vacuum tube must move to a new location, preferably a corner of the building.

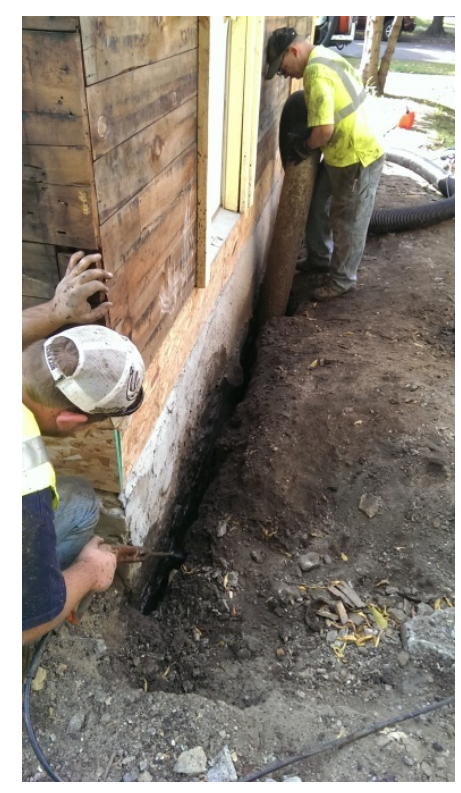

Figure 9. The vacuum tube and water wand

Figure 10 shows how precise the trench created by the hydrovac can be with stable soils and minimal debris. 


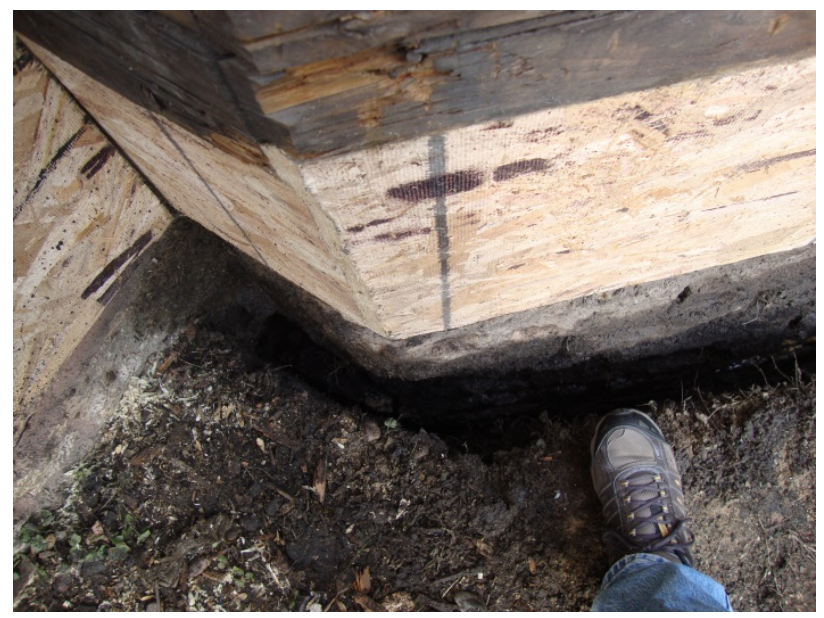

Figure 10. The trench after vacuuming

One question we had prior to undertaking the study was what we would find in the soil during the trenching process. Of major concern was the potential for soft soil to give way and fall into the hole, leaving a large gap. This did occur during the project, but the vacuum was able to quickly clear the loose soil so the crew could continue trenching (Figure 11).

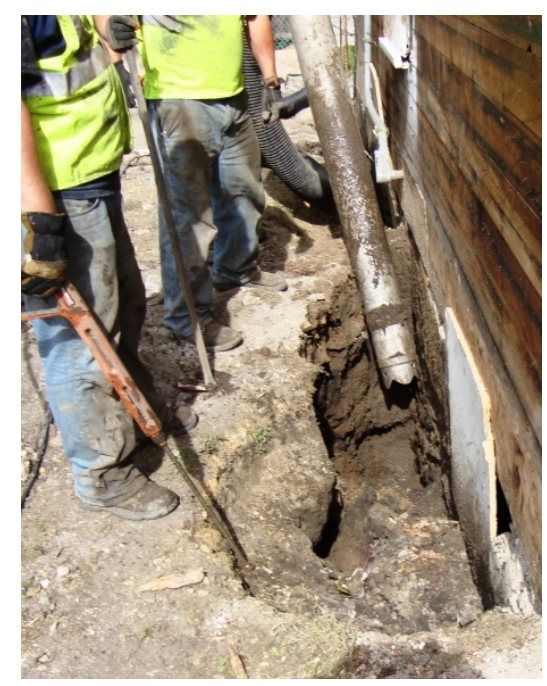

Figure 11. Soil collapse being cleared by vacuum

The soil near the foundation contained dozens of rocks that had to be pulled out by hand. There was a considerable amount of debris including metal and glass buried along with several old service pipes of unknown type (Figure 12). 


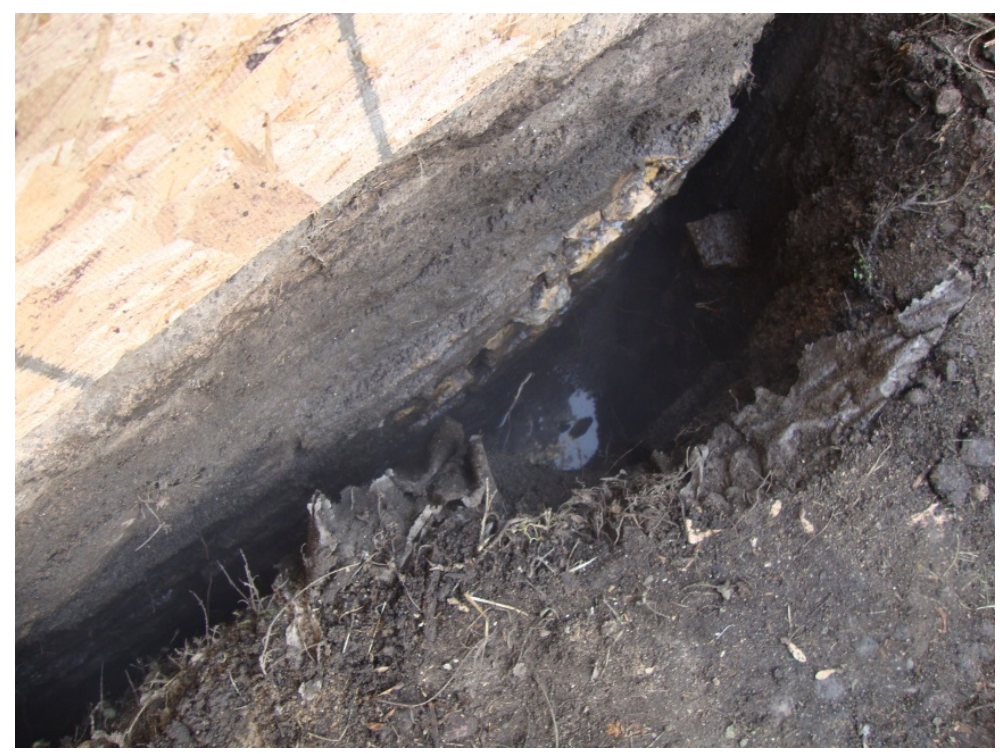

Figure 12. Debris encountered during trenching

The excavation contractor was able to complete the task of excavating around the whole foundation in 12 hours, including travel time to and from the shop and the dump site. The contractor told the team that this one experience provided him with ideas on how to improve the next installation. He estimated that digging $6 \mathrm{ft}$ deep around a $30-\mathrm{ft} \times 40$ - $\mathrm{ft}$ house with relatively clean fill could take as little as 6 hours-or, half the time it took for this first project.

\subsection{Obstacles}

One of the critical benefits of the hydrovac excavation method is the ability to excavate under porches, sidewalks, driveways, retaining walls, and air conditioning units, which cannot be accomplished with conventional excavation. The equipment is capable of cutting a narrow trench approximately $8 \mathrm{ft}$ down and $6 \mathrm{ft}$ horizontally. To tunnel under a 12-ft wide driveway, for instance, the excavator would tunnel $6 \mathrm{ft}$ from each side of the driveway toward the center. In situations where the obstacle is greater than $1 \mathrm{ft}$ wide or one side of the obstacle can't be accessed, a sawcut is made through the obstacle 4 in. from the foundation. The 4 -in. piece is removed to allow for excavation. Repair is required after completion of the job.

A concrete stoop is typically not a problem according to American Environmental; however, in this study we were not able to excavate under the front stoop of the house (Figure 4). After digging a few feet it became obvious there was a significant amount of concrete dumped in a hole under the slab and the slab was poured on top of the buried concrete. This made access to the foundation wall very difficult. It was decided to apply closed cell spray polyurethane foam on a portion of the interior foundation wall to make up for the absence of insulation and air sealing on this section.

\subsection{Insulation Process}

\subsubsection{Below-Grade Insulation}

Adding liquid foam insulation to the trench was fairly straightforward, as shown in Figures 13 through 15. The insulation contractor, Cocoon, dispensed the foam in the same manner as 
pressurized closed cell foam, using the same equipment, but with a special nozzle that squirted the liquid through a small tube. The foam rose rapidly in the trench as it cured. The operator used approximately $10 \mathrm{in.} \mathrm{lifts} \mathrm{back} \mathrm{and} \mathrm{forth} \mathrm{within} \mathrm{a} \mathrm{length} \mathrm{of} \mathrm{trench} \mathrm{until} \mathrm{the} \mathrm{desired} \mathrm{elevation} \mathrm{was}$ reached. Our design called for the foam to terminate at 6-12 in. BG in order to install the AG rigid foam/liquid foam finishing process. This transition to the rigid foam would provide a smooth surface for the application of a stucco-type parge.

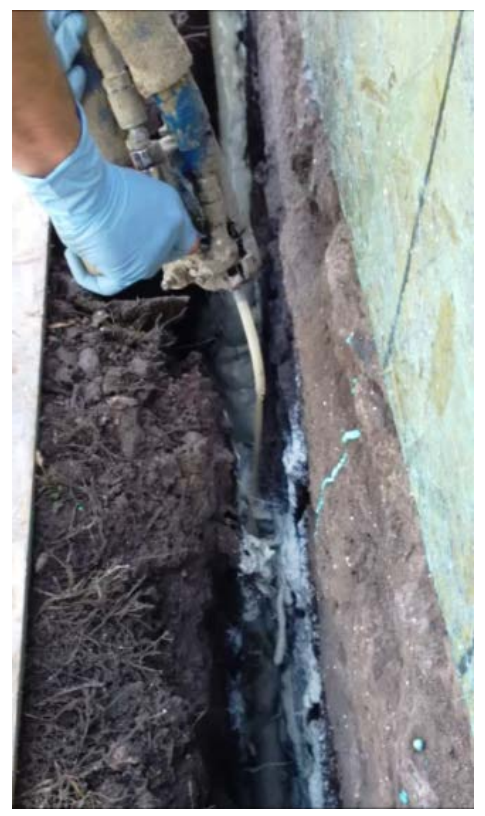

Figure 13. Dispensing liquid foam

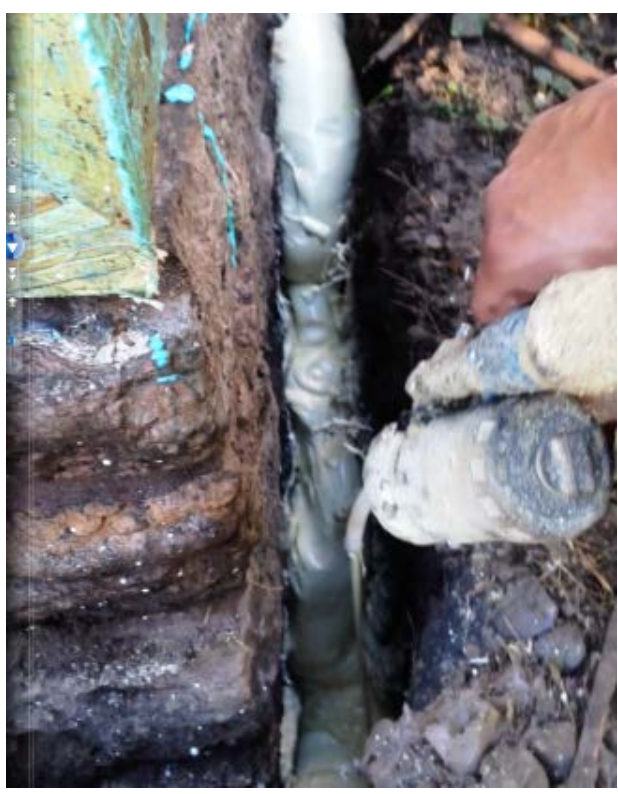

Figure 14. The operator using a 10 -in. lift process 


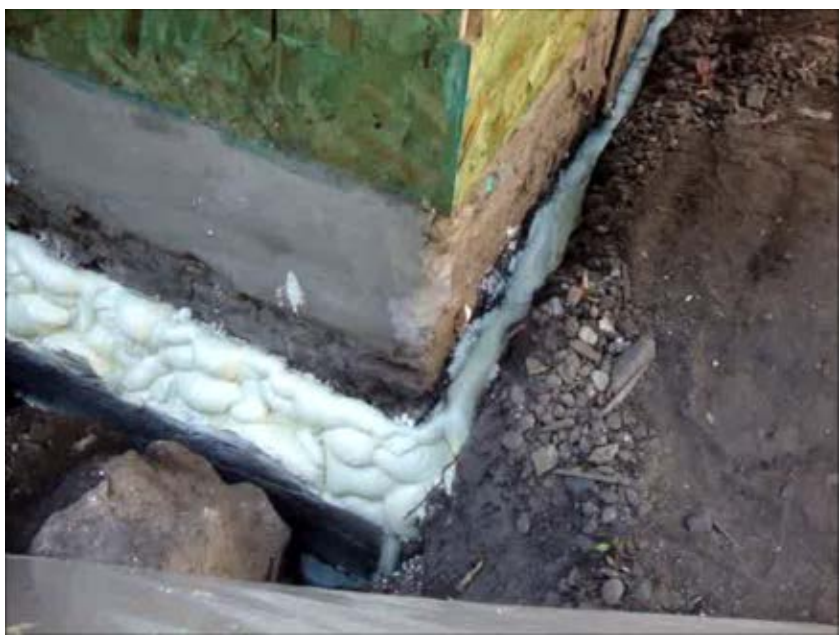

Figure 15. Foam terminated 6-12 in. BG

In areas where the soil collapsed during trenching, the resulting trench was wider than the desired $4 \mathrm{in}$. The crew from Cocoon addressed this issue by fashioning a panel form that was inserted into the trench to contain the foam expansion as it cured (see Figure 16).

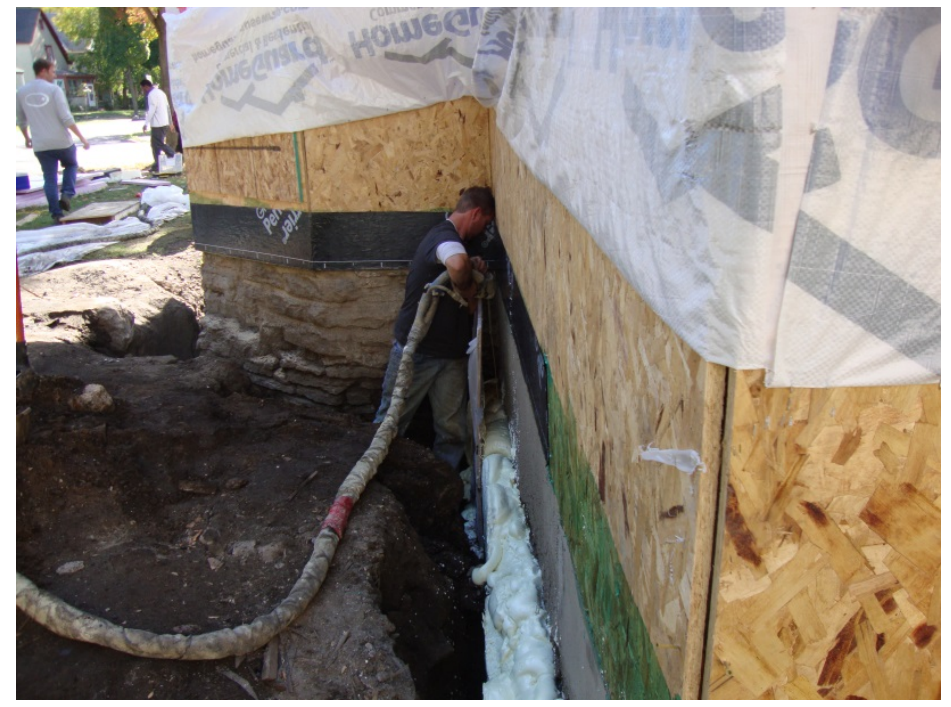

Figure 16. Rigid panel used to contain liquid foam in areas of soil collapse

\subsubsection{Above-Grade Insulation}

The design for AG insulation called for a smooth surface from the top of the rim joist to 6-12 in. BG so the general contractor could later apply a parge coat. Figures 17 through 20 demonstrate the process of preparing the rigid/liquid foam hybrid insulation. Wood stand-offs, $1 \frac{1 / 2 \text {-in. thick }}{1}$ square by 10 -in. length, were fastened to the rim joist with screws. The $1 \frac{1}{2}$-in. thick XPS was fastened to the wood standoffs. The resulting cavity provided room for the liquid foam to expand along the rough side of the foundation wall down to the BG foam to form continuous foundation insulation. 


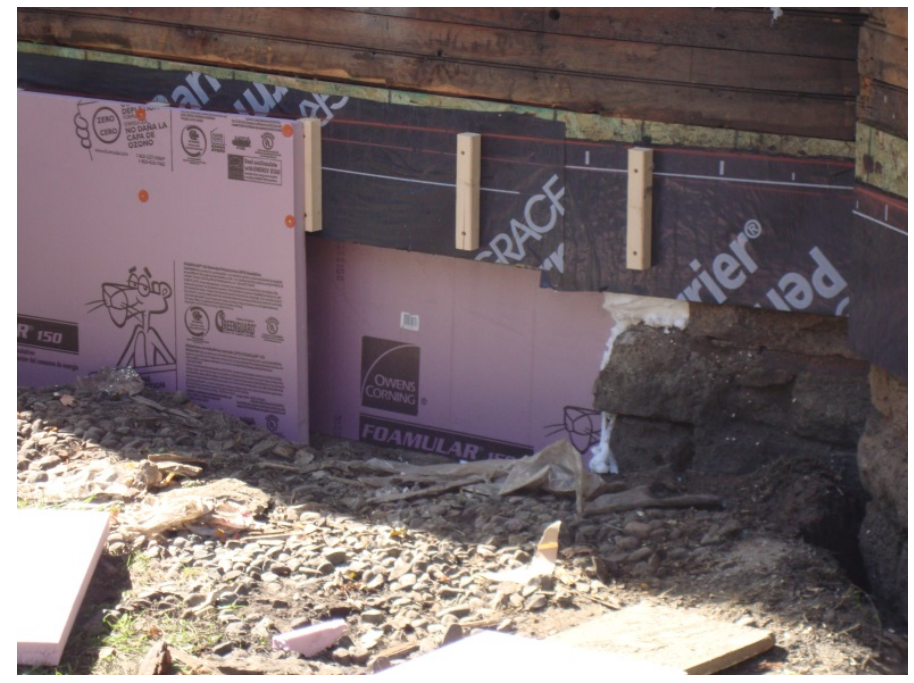

Figure 17. Wood standoffs attached to rim

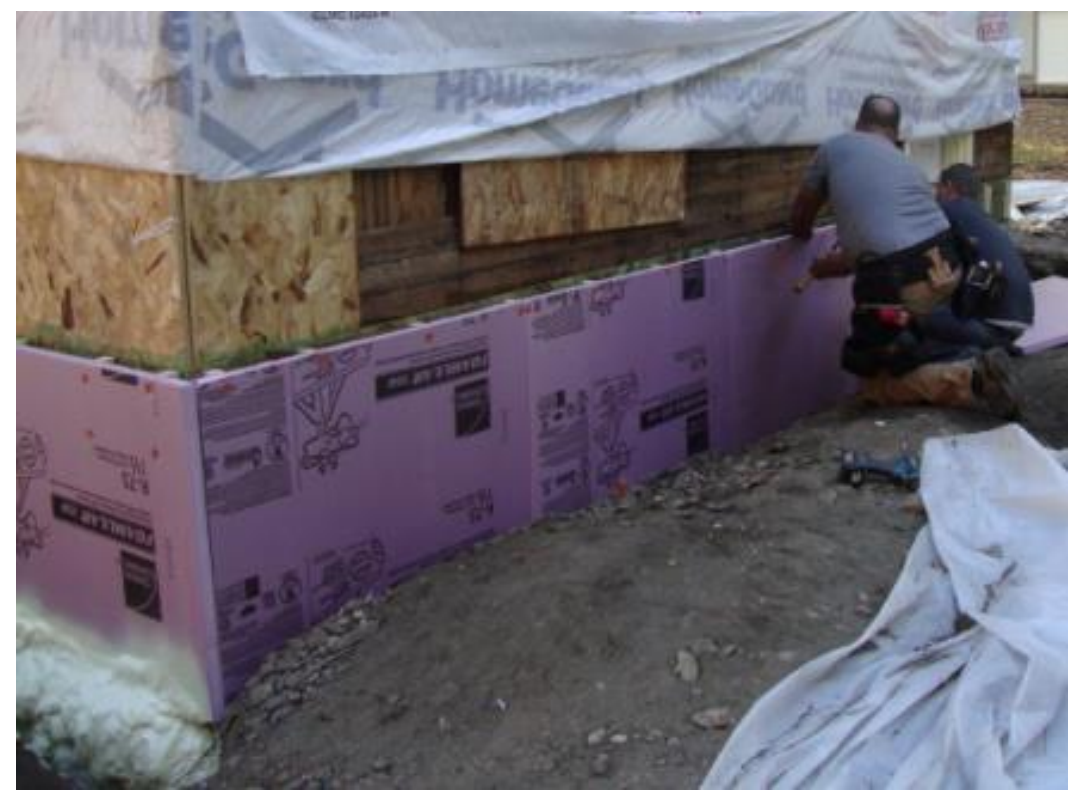

Figure 18. Smooth XPS foam board attached to wood standoffs 


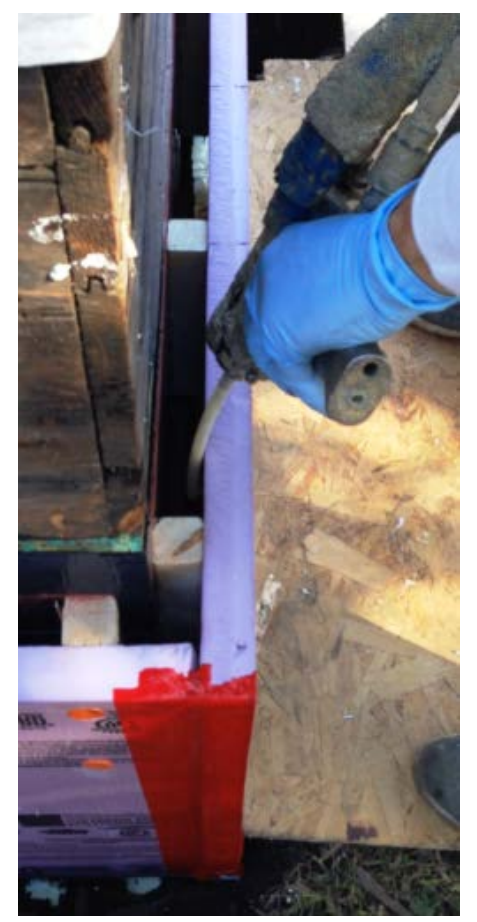

Figure 19. Liquid foam dispensed between wall and XPS

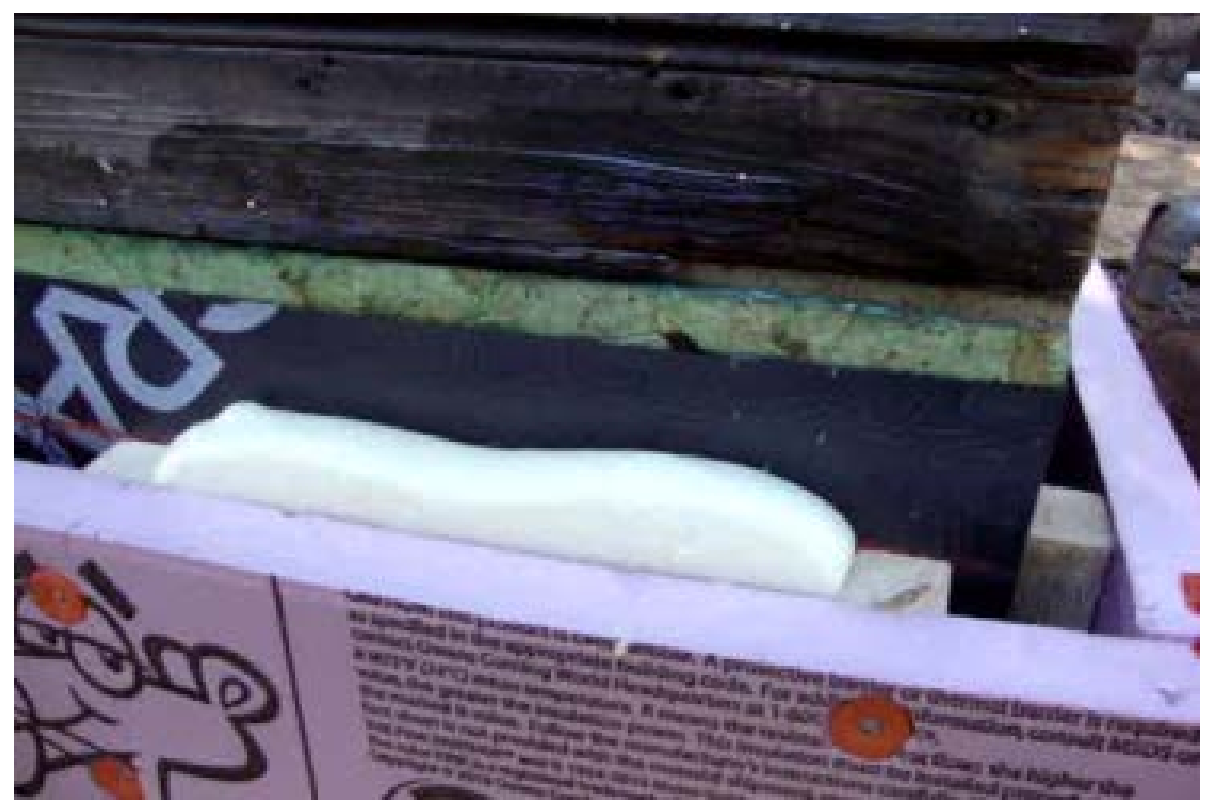

Figure 20. View of above-grade wall after liquid foam was added

As the first application of foam rose behind the XPS, it was immediately observed that the foam was able to push the XPS slightly out of alignment as it cured. The solution was to attach a 2-ft $\times$ 
8-ft sheet of plywood temporarily to the outside of the XPS by fastening it with screws driven into the standoffs (Figure 21). It was removed once the liquid foam hardened.

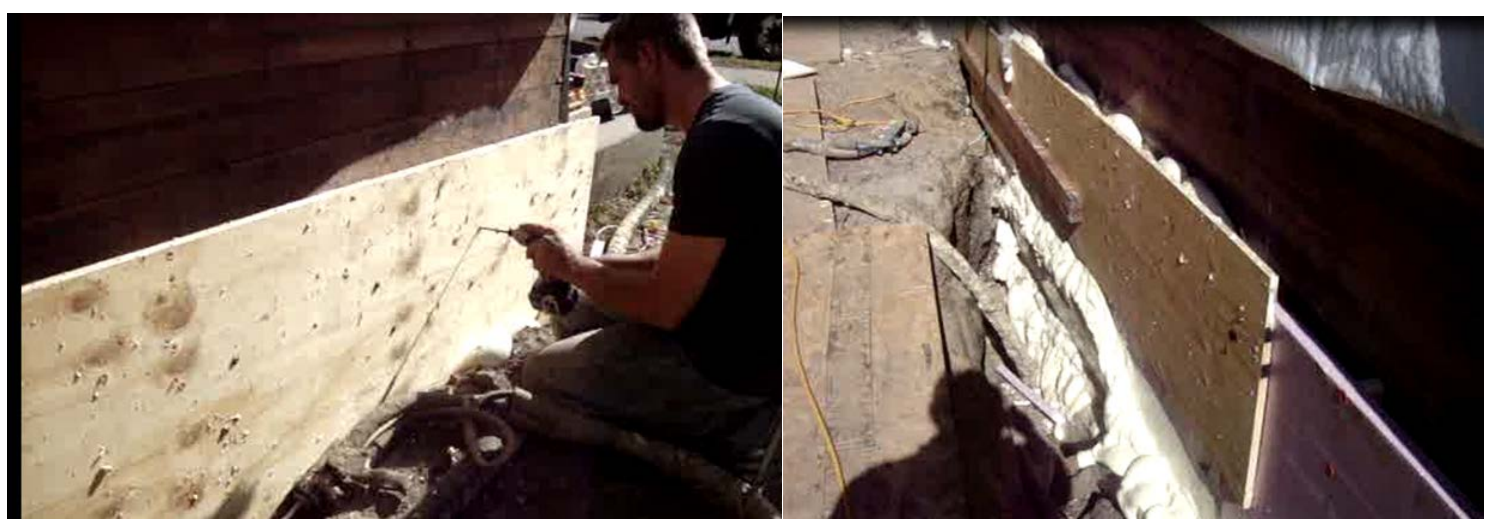

Figure 21. Temporary plywood to control foam expansion

After the AG foam cured, the excess was trimmed off, the plywood supports were removed, and the job was complete (Figure 22).

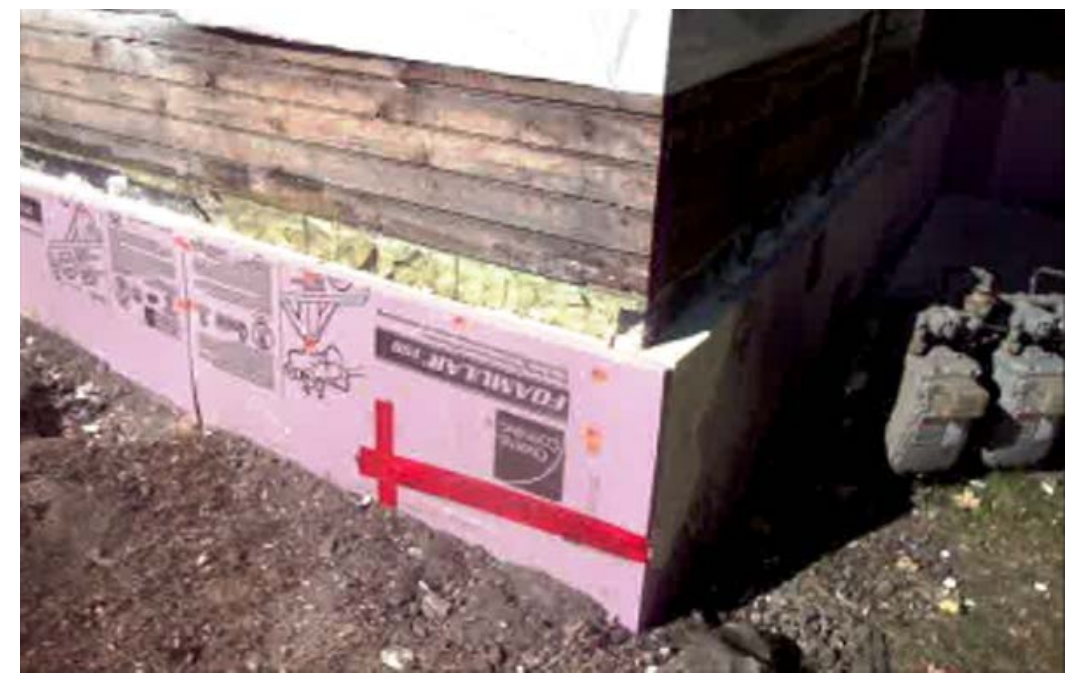

Figure 22. Final result of XPS/liquid foam AG insulation

\subsection{Transition to Wall Cladding}

While the excavationless process is designed to minimize the trench width, there will be an added thickness where the AG wall transitions to the rim. How this area is addressed depends on wall cladding material and work being done on the AG wall. Figure 23 is a final image from one of the study homes in Minnesota that underwent traditional backhoe trenching and exterior insulation in the previous excavationless report (Mosiman et al. 2012). A secondary trim board 
with beveled cap was added between the top of the metal-capped rim and the existing wall cladding as a step transition to address the plane change and minimize the visual difference.

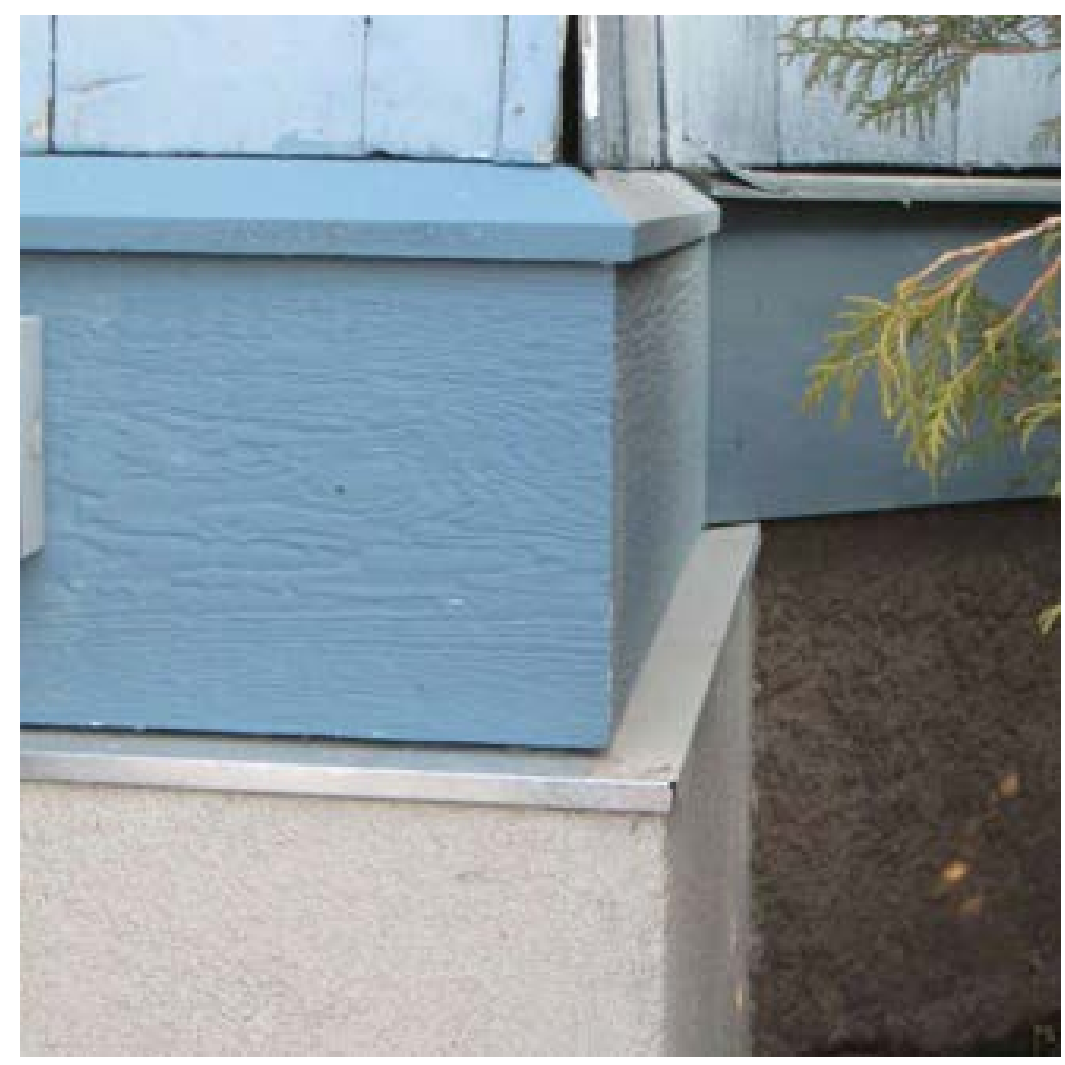

Figure 23. Step design at wall/rim transition

The project home in this study will be insulated from the exterior with rigid foam board insulation. As a result, the difference in depth between the wall and rim will be minimized. Figure 24 illustrates recommended materials and the layering process to align the air and thermal boundaries of the new external wall and foundation insulation while promoting water drainage. 


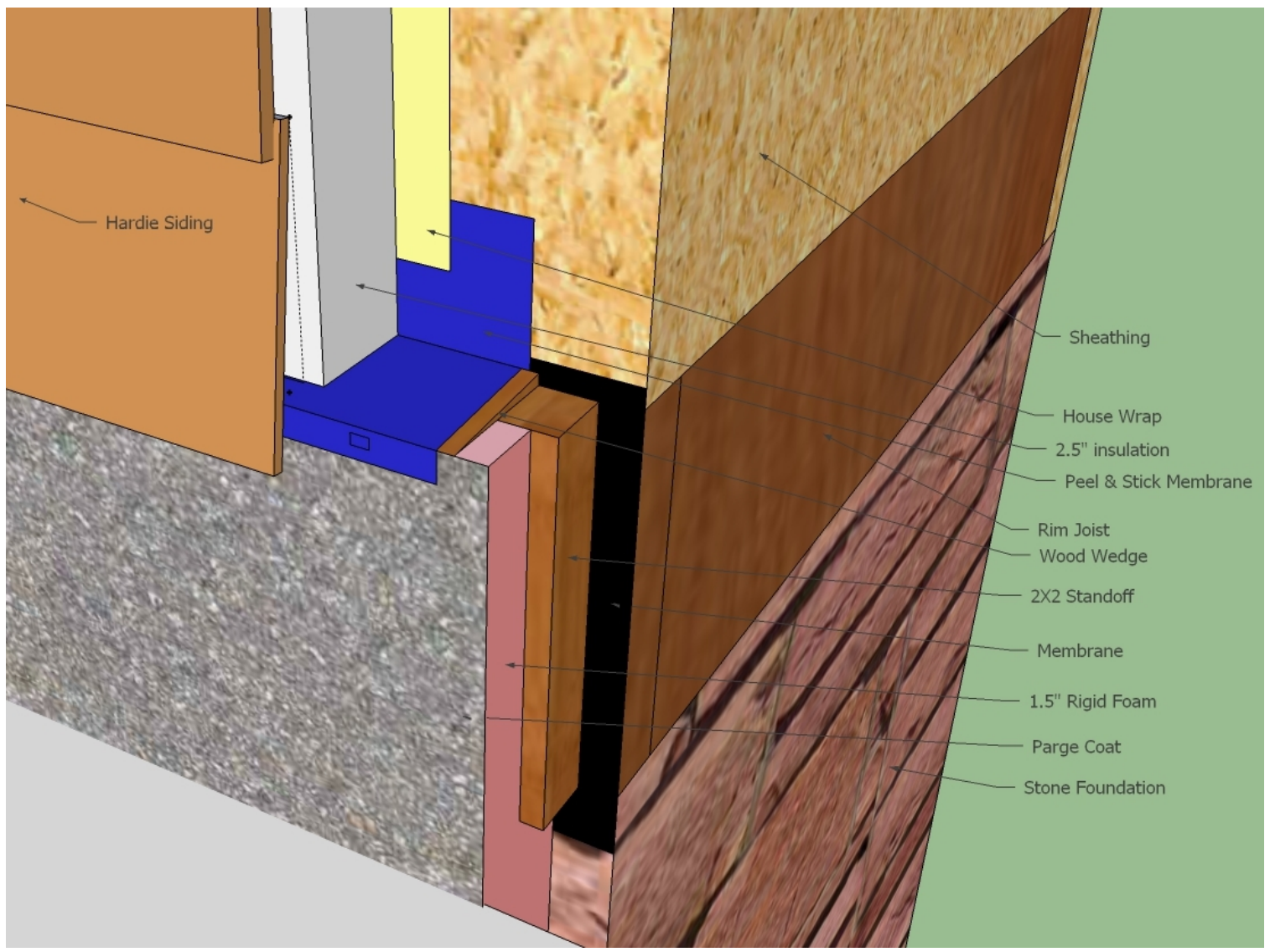

Figure 24. Transition of external wall and foundation insulation 


\section{Cost Analysis}

Table 1 represents a comparison of costs for foundation insulation applied to a reference home with a 28 - $\mathrm{ft} \times 36$ - $\mathrm{ft}$ foundation using a traditional backhoe and the excavationless processes. In all cases, the average exposed height $\mathrm{AG}$, including the rim, is $1.5 \mathrm{in}$. The AG area (128 linear $\mathrm{ft}$ $\times 1.5 \mathrm{ft})$ is $192 \mathrm{ft}^{2}$. The average BG depth is $4 \mathrm{ft}, 6 \mathrm{in}$. The excavation area $(128$ linear $\mathrm{ft} \times 4 \mathrm{ft}$, 6 in.) is 576. Total insulation area is $768 \mathrm{ft}^{2}$. Barriers such as sidewalks and porches were not considered.

The cost numbers in row 1 are based on a traditional foundation retrofit project using a backhoe, water barrier applied to the foundation wall, and R-15 XPS insulation. The costs for the traditional backhoe excavation and water barrier were acquired by interviewing contractors in the Minneapolis, Minnesota region.

Row 2 represents the cost numbers applied to the excavationless process used in the field study. The BASF liquid foam cost $\$ 1.50 / \mathrm{ft}^{2}$. To create the 4-in. trench, the hydrovac contractor charged $\$ 275 / \mathrm{h}$. While the field study took more than 12 hours to complete, the hydrovac contractor estimated that lessons learned on the first project should enable him to cut his time in half on subsequent projects. He did note, that final costs for any project are subject to change from an estimate due to unforeseen circumstances such as rocks, debris, and cave-ins encountered during the trenching process.

Row 3 is a newly proposed method that was developed by the insulation contractor after their involvement with the field study. Rather than filling the trench with 4 in. of liquid foam and using the hybrid XPS/liquid foam AG, the hybrid XPS/liquid foam would be used from bottom of trench to top of rim. This would allow the less costly XPS to replace some of the liquid foam.

In this newly suggested process, 1 -in. thick wooden spacers would be used to hold 8 - $\mathrm{ft} \times 4$ - $\mathrm{ft} \times 1$ $1 / 2$-in. rigid XPS against the foundation wall. The liquid foam would be poured into the gap created by the spacers. A sheet of plywood would be attached at the rim temporarily to prevent the XPS from bowing. 
Table 1. Comparison of Costs: Excavationless Versus

Traditional Foundation Retrofit With Backhoe

\begin{tabular}{|c|c|c|c|c|c|c|c|}
\hline Retrofit Approach & $\begin{array}{c}\text { Insulation } \\
\text { Type }\end{array}$ & $\begin{array}{c}\text { Nominal Wall } \\
\text { R-Value }\end{array}$ & $\begin{array}{c}\text { Material } \\
\text { Cost }\end{array}$ & $\begin{array}{c}\text { Labor } \\
\text { Cost }\end{array}$ & $\begin{array}{l}\text { Cost } / \mathbf{f t}^{2} / \\
\text { R-Value }\end{array}$ & $\begin{array}{c}\text { Excavation } \\
\text { Cost }\end{array}$ & $\begin{array}{l}\text { Total } \\
\text { Cost* }\end{array}$ \\
\hline $\begin{array}{c}1 \\
\text { Traditional } \\
\text { Excavation }\end{array}$ & $\begin{array}{c}3 \text {-in.XPS@ } \\
\$ 1.25 / \mathrm{ft}^{2}\end{array}$ & $\mathrm{R}-15$ & $\begin{array}{l}\text { \$960 XPS, } \\
\$ 833 \text { for } \\
\text { water } \\
\text { barrier }\end{array}$ & $\$ 2,880$ & $\$ 0.40$ & $\begin{array}{c}\$ 2,920 \\
\text { (traditional } \\
\text { power } \\
\text { shovel }\end{array}$ & $\$ 7,593$ \\
\hline $\begin{array}{c}2 \\
\text { Excavationless as } \\
\text { Applied in the Field } \\
\text { Study }\end{array}$ & $\begin{array}{l}\text { Liquid foam (4 } \\
\text { in.) BG, } \\
\text { hybrid } \\
\text { XPS/liquid AG }\end{array}$ & R-20 (ave) & $\begin{array}{c}\$ 4,224 \mathrm{BG}, \\
\$ 698 \mathrm{AG}\end{array}$ & Included & $\$ 0.32$ & $\begin{array}{c}\$ 1,650 \\
\text { (hydrovac) }\end{array}$ & $\$ 6,572$ \\
\hline $\begin{array}{c}3 \\
\text { Excavationless With } \\
\text { Proposed Changes }\end{array}$ & $\begin{array}{l}\text { 1.5-in. XPS } \\
\text { plus } 1 \text {-in.liquid } \\
\text { foam from top } \\
\text { of rim to bottom } \\
\text { of trench }\end{array}$ & $\mathrm{R}-12.5$ & $\$ 2,142$ & Included & $\$ 0.22$ & $\begin{array}{c}\$ 1,650 \\
\text { (hydrovac) }\end{array}$ & $\$ 3,792$ \\
\hline
\end{tabular}

*Does not include repairs to landscape, building structures such as porches and stoops, exterior features such as driveways, sidewalks, patios, or utilities. 
The table of comparisons demonstrates a $23 \%$ reduction in cost from the traditional excavation process to the excavationless field study. The final cost of the traditional excavation process, however, is not indicative of final true costs. Final true costs will vary, but may include repairs to landscape, building structures such as porches and stoops, exterior features such as driveways, sidewalks, patios, or utilities. These costs often create the hurdle that prevents homeowners from insulating foundations from the exterior. The advantage of the hydrovac process is that disruption to landscaping, structures, exterior features, and utilities can be minimal.

The excavationless process with proposed changes (row 3) highlights additional cost reduction opportunities discovered during the field study. Using the hybrid XPS/liquid foam from top of rim to bottom of trench reduces the total cost by $35 \%$. When the International Energy Conservation Code is adopted, however, an additional $1 / 2$ in. of XPS will be needed to meet the R-15 code requirement. Using today's XPS cost would result in an additional cost to the project of $\$ 384$. 


\section{Conclusions}

\subsection{Research Questions}

The following summarizes responses to the research questions based on the application of the excavationless process in the field.

\section{What is the impact of hydrovac equipment on landscaping?}

The abandoned home that served as our test house had no landscaping other than grass. Significant disruption to the yard had already been done by the general contractor to prepare the home for the improvements that would occur after the foundation insulation was added. This provided the opportunity to work around the home with minimal concern as we installed the excavationless process for the first time and addressed unexpected issues.

In a home with established landscaping, the precision of the hydrovac process allows minimal excavation of roughly 3-4 in. around the perimeter of the foundation. This width from the foundation should not impact properly planted landscape trees, shrubs and plants. In future projects, landscape items could be fenced or covered temporarily to prevent accidental harm from the workers and equipment. A temporary plywood walkway could also be used along the foundation or on the grass to reduce the risk of impact.

\section{What issues result when digging a narrow trench around a foundation?}

During excavation there is the possibility of soil cave-ins with unstable soils or debris from previous construction work. The hydrovac equipment can remove loose soil and small debris, leaving a clean hole. Upon completion of work, the hole would need to be filled.

The hydrovac is capable of tunneling under obstacles to remove soil. The ability of the hydrovac to get the job completed as planned is dependent upon unknown obstacles in the soil. In this study, concrete debris under the front porch prohibited the use of the excavationless process. Insulation of that portion of the foundation wall had to be done from the inside instead of the outside.

\section{How are obstacles such as sidewalks and stoops handled?}

The hydrovac used in this excavation was capable of tunneling $8 \mathrm{ft}$ down and $6 \mathrm{ft}$ horizontally. If the obstacle is wider than $12 \mathrm{ft}$ or there is no access to the obstacle from both sides, a 4-in. sawcut can be made in the obstacle to gain access to the foundation. The obstacle will need repair upon completion.

\section{How is the insulation handled AG in order to minimize costs and maximize benefits of the system?}

This field installation provided the team with plenty of opportunities to learn how to improve on ideas that were envisioned during the design phase. This installation used a hybrid system of rigid XPS and liquid foam AG that was connected to the BG liquid foam. The XPS AG provided a smooth surface to accept architectural materials while the liquid foam could fill in the uneven 
surfaces of the rim. In future installations it is recommended that the AG hybrid approach be used from the top of the rim to the bottom of the trench, eliminating the need for a different approach below and AG.

\section{How are transition details handled from AG insulation to the wall?}

These details are dependent upon the style of the home and the difference in thickness of the AG wall and the new foundation insulation. In this home, the contractor will be adding external insulation to the home, bringing the plane of the wall in line with the foundation. Appropriate water and air management materials will be engaged but the transition details are minimal.

If the AG wall is not altered and a large transition occurs, adding an additional trim board at the rim can help create a step process and minimize the visual impact.

\section{What are the costs associated with installation of the system?}

The installed costs (materials and labor) for the excavationless method applied to the home in Minneapolis included the hydrovac truck, XPS foam, and liquid foam insulation. Compared to a reference home using traditional excavation methodology, the excavationless process in the field study reduced costs by $23 \%$. Not included were any costs to repair cave-ins caused by the hydrovac process. In this project, they will be incurred by the general contractor as part of the overall project. Costs for this type of project in other regions of the state and country would be dependent upon labor costs and access to hydrovac contractors.

The proposed method of using the hybrid XPS/liquid foam from top of rim to bottom of trench could potentially reduce excavationless costs by an additional $35 \%$.

Both the numbers from the field study and the proposed changes to the process represent a cost savings over the traditional excavation method of nearly $50 \%$ with the loss of some R-value. The excavationless process would result in even greater savings since replacement of building structures, exterior features, utility meters, and landscaping would be minimal or nonexistent in an excavationless process.

\subsection{General Conclusions}

This one field study provided plenty of opportunities to learn about the practical application of the excavationless process. In a matter of two days and with minimal impact to the yard, a 4-in. trench was created around the foundation of the test house and filled with a liquid insulation. The process was relatively straightforward since both processes and materials have been used in the field but never together. The test home is now fully insulated at the foundation and rim from the exterior. A means to reduce the cost of a second installation have already been developed.

The hydrovac process confers an additional benefit to homes in cold climates. The 450,000 Btu water heater located on the truck will instantly melt frost and allow for trenching during cold weather months. The liquid foam can be kept warm during application enabling the excavationless trenching and insulation process to be used during the winter. 
While the process of using the excavationless method to apply exterior foundation insulation appears to be very successful, there are still unknown impacts. Hygrothermal testing would be an important step to help understand the role of the exterior insulation as a water management plane.

The feasibility and cost to install draintile using the excavationless process were not part of this study. Studying both in future excavationless installations would continue to help refine the steps that can be included in an excavationless process to address bulk water management and determine costs to do so.

The excavationless process could also be used as part of a deep energy retrofit from foundation to roof with minimal transition at the rim when external AG wall insulation is used. It would also promote thorough alignment of the water and air barriers at the rim/foundation wall transition.

The market for this measure is very broad. There are tens of millions of existing homes in cold climates with uninsulated basements, partial basements, crawl spaces, and slabs. Homes with finished basements, expensive landscaping, and other barriers, such as porches, can be helped. Homes in need of water proofing, drain tile, or repair will also benefit. Excavationless provides a cost-effective, exterior-side foundation insulation system for existing homes that could be deployed by the industry while avoiding many of the health and moisture-related issues common to many interior insulation retrofits. 


\section{References}

Carmody, J.; Christian, J.; Labs, K. (2005). Builder's Foundation Handbook. Honolulu:

University Press of the Pacific.

Fugler, D. (2002). "Dry Notes from the Underground. Home Energy.” Berkeley, CA: Energy Auditor and Retrofitter, Inc.

Lstiburek, J.; Yost, N. (2002). "Basement Insulation Systems.” Building Science Corporation; Westford, MA.

Mosiman, G., Wagner, R., Schirber, T. (2012). "Excavationless Exterior Foundation Insulation Exploratory Study.” National Renewable Energy Laboratory; Golden, Co.

Swinton, M.C.; Bomberg, M.T.; Kumaran, M.K.; Normandin, N.; Maref, W. (1999).

"Performance of Thermal Insulation on the Exterior of Basement Walls." National Research Council of Canada, Construction Technology Update No. 36; National Institute for Research in Construction: Ottawa, Canada.

U.S. Census (2011). "2011 American Housing Survey.” United States Department of Commerce, Washington D. C.

http://factfinder2.census.gov/faces/tableservices/jsf/pages/productview.xhtml?pid=AHS_2011_C 01AO\&prodType=table Accessed April 4, 2014. 


\section{Appendix: Solution Center Guide Submission}

\section{Guide Title: Exterior-Side Foundation Insulation for Existing Homes}

Keywords: Thermal enclosure, walls below grade, foundation insulation, liquid insulating foam, hydrovac excavation technology

Climate Zone: All climate zones

Construction Type: Existing Homes

Scope: Thermal Enclosure Upgrades for Existing Homes

Install exterior foundation insulation on foundation walls, crawlspaces, and slab edges that meet or exceed local code requirements or the most recent International Energy Conservation Code. Install insulation without misalignments, compressions, gaps or voids in all wall cavities along the thermal barrier of the house.

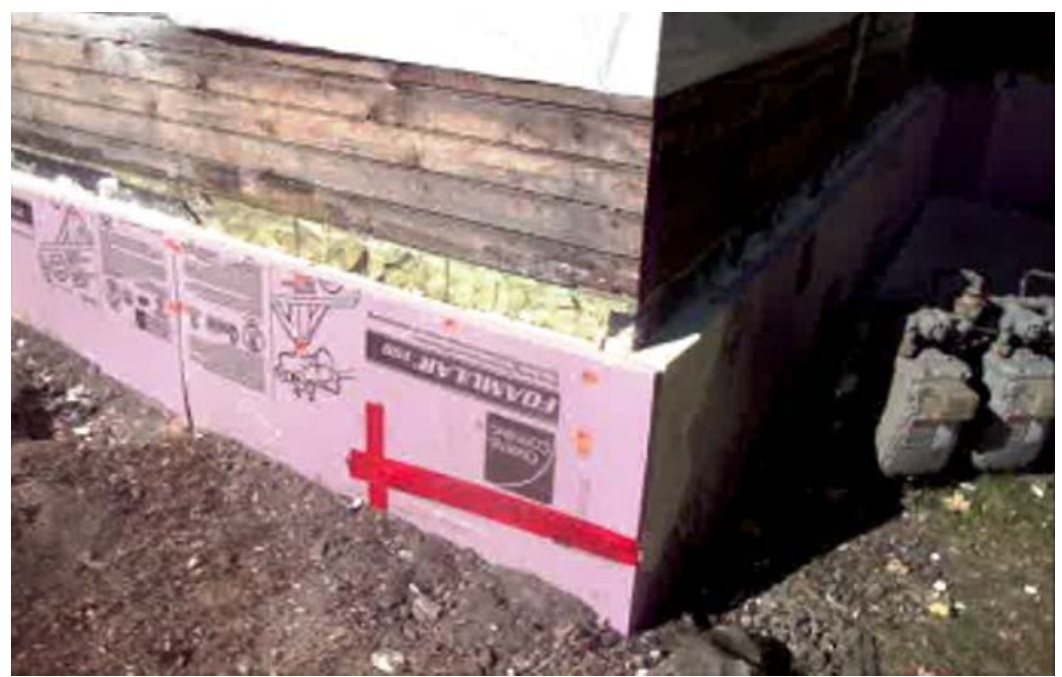

Image Title: Continuous Rigid/Liquid Foam Exterior Insulation

Image Source: NorthernSTAR Team, University of Minnesota, 2013, unpublished.

Display Image Filename: NS_rigid-liquid-exterior-scope_TE.jpg

A. Determine desired R-value of exterior foundation insulation.

B. Excavate 3" to 4" wide trench along existing foundation wall using hydrovac pressurized water system and vacuum extraction to desired depth. Width of trench determined by final R-Value desired considering the following:

a. Liquid insulating foam R-5/inch

b. XPS R-5/inch

C. Attach 1" thick wood stand-offs to rim.

D. Attach XPS rigid insulation with polyethylene outer layer facing soil to wood stand-offs.

E. Apply temporary bracing to rigid foam 
F. Pour closed cell polyurethane liquid insulating foam, R-5, into gap between wall and rigid foam using 10 " lifts back and forth across trench to desired elevation.

G. Remove temporary bracing.

H. Trim foam even with top of XPS 


\section{Description}

Foundation walls almost always experience variations in temperature and drying potential from the top (above grade) to the footing (below grade), from season to season, and from wall to wall depending on solar orientation and design. Lack of waterproofing, capillary breaks, and drainage at the footing provide further risk for increased moisture stress resulting from bulk water intrusion or capillary wicking. Interior insulation and the presence of vapor impermeable materials can further exacerbate the ability of a foundation wall to dry to the interior - creating continually wet insulation and building materials. Temperature difference from top of the wall (above grade) to the bottom (below grade) may also exacerbate the movement of water vapor towards the sill and rim - especially in hollow core masonry block. Moisture accumulation may lead to deterioration and rot of the building structure components, loss of energy efficiency and occupant comfort, as well as the opportunity for mold growth and resultant poor indoor environmental quality.

Insulating existing foundation walls can be time and cost efficient using the excavationless process that combines hydrovac excavation technology with liquid insulating foam. The hydrovac technology consisting of pressurized water system and vacuum extraction enables precise trenching adjacent to the foundation with minimal disruption and in minimal time compared to traditional backhoe excavation.

Applying closed cell foam insulation to the exterior of the foundation and implementing proper bulk water management strategies greatly reduces the risks related to water/vapor flow and foundation wall temperature differential. The liquid insulating foam from BASF can be used below grade and in contact with soils and moisture. It is a cast-in-place, naturally hydrophobic closed cell polyurethane foam, R-5/inch, where $90 \%$ of the foam's mass is comprised of individual cells which will not allow for the transfer of moisture from one cell to another. In addition, a specialized formulation was developed for this specific application utilizing materials that would further reduce the chance for water intrusion and further increase its hydrophobicity while also enabling the foam to aggressively adhere to smooth or rough surfaces. The XPS has a polyethylene film added to the panel sides for vapor resistance.

\section{HOW TO}

Insulating a foundation wall from the exterior during new construction is the most cost-effective way to achieve the hygrothermal benefits of exterior foundation insulation. Existing homes can be upgraded with exterior foundation as well using a minimally invasive 2-step process involving both hydrovac excavation and liquid foam application in a technique called excavationless.

1. Check with local authorities to ensure all materials and work will comply with local code requirements such as the R-value of foundation insulation.

2. Evaluate perimeter of foundation for obstacles. Hydrovac pressure wand can reach 6' under obstacles in one direction. Patios and driveways greater than 6' that are accessible only from one side might require a 4" saw cut near the foundation to accommodate the water wand and vacuum. Patios and driveways up to 12' wide with access on both sides can be accommodated by the hydrovac process. Built structures greater than 6' with access on only one side may need to be removed. 
3. General contractor or insulation contractor to prepare the site and project:

a. Use temporary fencing to protect landscape elements.

b. Lay down plywood walk-way for workers if space permits.

c. Apply temporary protection to protect first floor windows located close to work area.

d. Repair any wood rot at rim.

e. Order BASF liquid insulating foam directly from BASF. Foam to be shipped to regional distributors as needed until the demand grows. (It would be recommended to contact the authors first for direct connections.

4. Hydrovac contractor to excavate a trench alongside the foundation wall 3 " wide to desired depth using truck-mounted pressurized water system and portable pressurized water system combined with vacuum extraction.

a. Start in center of wall. Create 8 " wide hole using pressurized water.

b. Position 8 " wide vacuum tube in center of hole

c. Dig 3" to 4" wide trench by moving water want away from stationary vacuum tube while keeping wand focused towards vacuum tube to direct soil-water slurry to it.

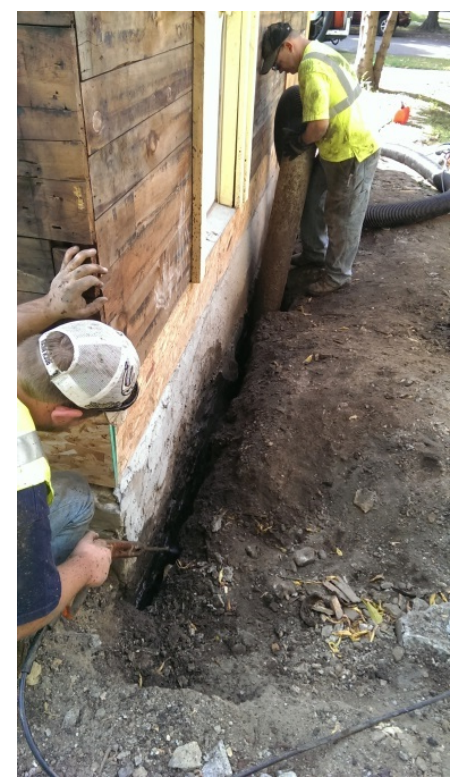

Image Caption: Figure 1. Water wand and vacuum extraction for digging trench. Image Title: Water wand and vacuum extraction for digging trench Image Source: NorthernSTAR team, University of Minnesota, 2013, unpublished. Display Image Filename: NS_water-wand-vacuum-extraction_TE.jpg

d. Create new 8" wide hole at corner of house and move wand to center of wall. Reposition vacuum in center of new wall.

5. Insulation contractor to screw 1.5 " thick wood stand-offs to wood rim. Attach 1-1/2" thick extruded polystyrene (XPS) to wood stand-offs starting at the top of the rim with the XPS reaching to bottom of trench. 


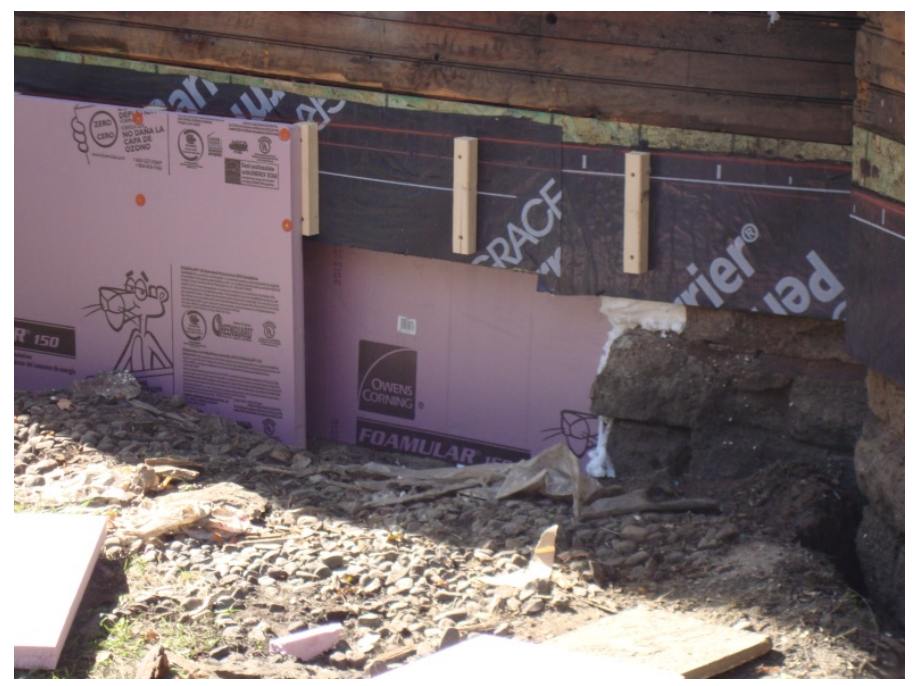

Image Caption: Figure 2. Wood stand-offs attached to rim.

Image Title: Wood stand-offs attached to rim

Image Source: NorthernSTAR team, University of Minnesota, 2013, unpublished.

Display Image Filename: NS_wood-stand-offs-rim_TE.jpg.

6. Position temporary plywood to foam at rim to prevent bowing while liquid foam cures

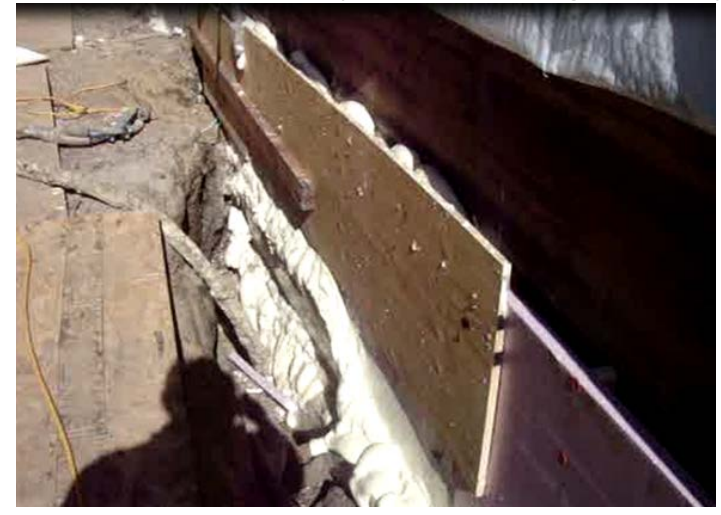

Image Caption: Figure 3. Temporary wood bracing.

Image Title: Temporary wood bracing

Image Source: NorthernSTAR team, University of Minnesota, 2013, unpublished.

Display Image Filename: NS_temp-wood-bracing_TE.jpg

7. Pour liquid foam into trench using $10^{\prime \prime}$ lifts back and forth across width of wall until foam reaches the top of the XPS 


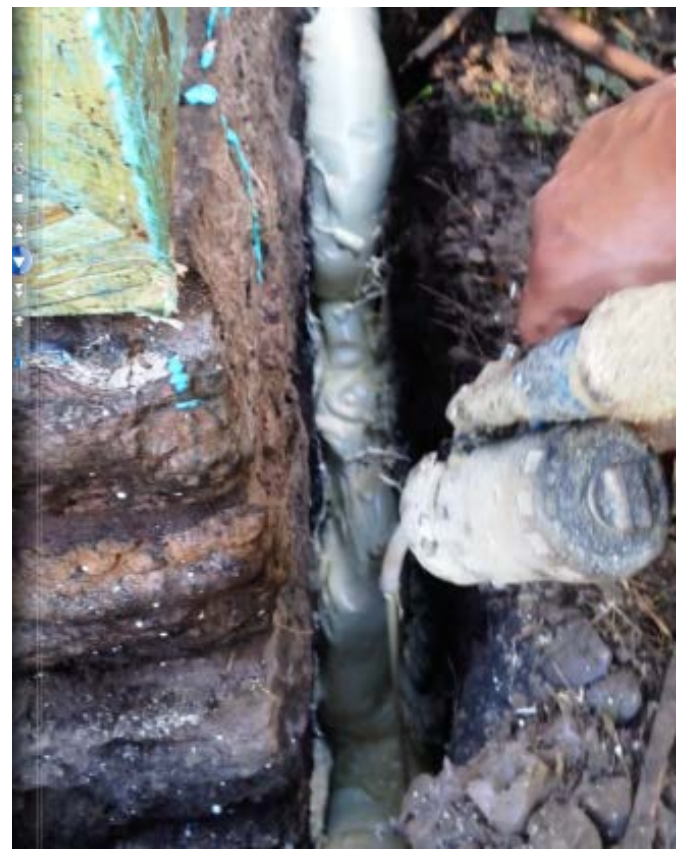

Image Caption: Figure 4. Pouring liquid foam into trench.

Image Title: Pouring liquid foam into trench

Image Source: NorthernSTAR team, University of Minnesota, 2013, unpublished.

Display Image Filename: NS_pouring-liquid-foam_TE.jpg

8. When foam is cured, remove bracing. Trim excess foam to top of XPS.

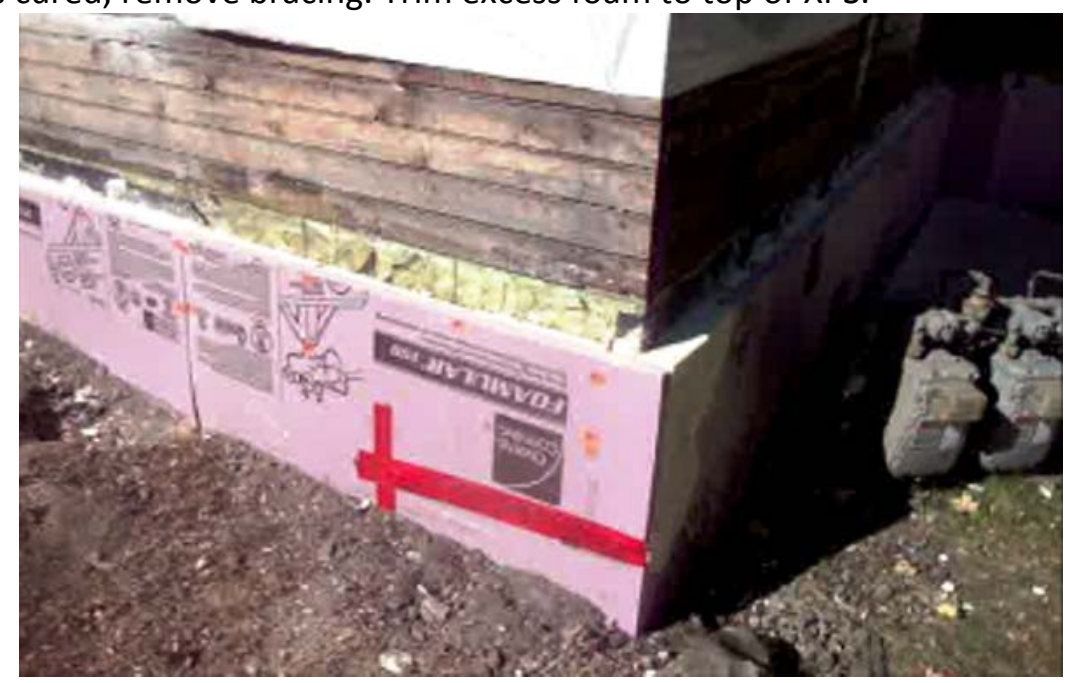

Image Caption: Figure 5. Finished insulation.

Image Title: Finished insulation

Image Source: NorthernSTAR team, University of Minnesota, 2013, unpublished.

Display Image Filename: NS_finished-insulation_TE.jpg 


\section{Ensuring Success}

\section{CODE COMPLIANCE}

Check with local authorities to ensure all materials and work will comply with local code requirements such as the R-value of foundation insulation.

\section{SITE EVALUATION}

The hydrovac equipment is capable of reaching 6' under obstacles in one direction. Patios and driveways greater than 6' that are accessible only from one side might require a 4" saw cut near the foundation to accommodate the water wand and vacuum in areas out of reach. Patios and driveways up to 12' wide with access on both sides can be accommodated by the hydrovac process. Built structures greater than 6' with access on one side only may need to be removed or partly removed for access.

\section{SITE PREPARATION}

Use temporary fencing to protect landscape elements.

Lay down plywood walk-way for workers if space permits.

Apply temporary protection to protect first floor windows located close to work area.

Repair any wood rot at rim.

\section{INSPECTION}

Visual inspection of the insulation installation will help identify areas in need of improvement prior to the addition of architectural elements or alignment of air, water, and thermal boundaries with above grade walls. 


\section{Climate-Specific Factors/Details}

The amount of insulation that must be installed on foundation walls in existing homes is specified by code and varies by climate. The U.S. Department of Energy Building Energy Code Program identifies the building codes currently in force for each state.

The following is a guide for insulation requirements by location for 2012 IECC with a comparison to 2009 IECC included.

Table 1. Minimum Insulation Levels for New Homes Required by the 2009 and 2012 IECC, Adapted from 2012 IECC Table R402.1.1 and 2009 IECC Table 402.1.1. (PNNL and ORNL 2012).

Table 2.1. Minimum Insulation Levels ${ }^{\text {a }}$ for New Homes as Required by the 2009 and 2012 International Energy Conservation Code.

\begin{tabular}{|c|c|c|c|c|c|c|c|c|c|c|c|c|c|c|}
\hline \multirow{2}{*}{$\begin{array}{l}\text { Climate } \\
\text { Zone }\end{array}$} & \multicolumn{2}{|c|}{$\begin{array}{l}\text { Ceiling } \\
\text { R-Value }\end{array}$} & \multicolumn{2}{|c|}{$\begin{array}{l}\text { Wood Frame Wall } \\
\text { R-Value }\end{array}$} & \multicolumn{2}{|c|}{$\begin{array}{c}\text { Mass Wall } \\
\text { R-Value }\end{array}$} & \multicolumn{2}{|c|}{$\begin{array}{c}\text { Floor } \\
\text { R-Value }\end{array}$} & \multicolumn{2}{|c|}{$\begin{array}{c}\text { Basement } \\
\text { Wall }^{e} \text { R-Value }\end{array}$} & \multicolumn{2}{|c|}{$\begin{array}{l}\text { Slab R-Value }{ }^{f} \\
\text { and Depth }\end{array}$} & \multicolumn{2}{|c|}{$\begin{array}{l}\text { Crawlspace }^{\mathrm{g}} \\
\text { Wall R-Value }\end{array}$} \\
\hline & $\begin{array}{l}2009 \\
\text { IECC }\end{array}$ & $\begin{array}{l}2012 \\
\text { IECC }\end{array}$ & $\begin{array}{l}2009 \\
\text { IECC }\end{array}$ & $\begin{array}{l}2012 \\
\text { IECC }\end{array}$ & $\begin{array}{l}2009 \\
\text { IECC }\end{array}$ & $\begin{array}{l}2012 \\
\text { IECC }\end{array}$ & $\begin{array}{l}2009 \\
\text { IECC }\end{array}$ & $\begin{array}{l}2012 \\
\text { IECC }\end{array}$ & $\begin{array}{l}2009 \\
\text { IECC }\end{array}$ & $\begin{array}{l}2012 \\
\text { IECC }\end{array}$ & $\begin{array}{l}2009 \\
\text { IECC }\end{array}$ & $\begin{array}{l}2012 \\
\text { IECC }\end{array}$ & $\begin{array}{l}2009 \\
\text { IECC }\end{array}$ & $\begin{array}{l}2012 \\
\text { IECC }\end{array}$ \\
\hline 1 & 30 & 30 & 13 & 13 & $3 / 4$ & $3 / 4$ & 13 & 13 & 0 & 0 & 0 & 0 & 0 & 0 \\
\hline 2 & 30 & 38 & 13 & 13 & $4 / 6$ & $4 / 6$ & 13 & 13 & 0 & 0 & 0 & 0 & 0 & 0 \\
\hline 3 & 30 & 38 & 13 & $20 / 13+5^{b, d}$ & $5 / 5$ & $8 / 13$ & 19 & 19 & $5 / 13^{h}$ & $5 / 13^{h}$ & 0 & 0 & $5 / 13$ & $5 / 13$ \\
\hline $\begin{array}{l}4 \text { except } \\
\text { Marine }\end{array}$ & 38 & 49 & 13 & $20 / 13+5^{b, d}$ & $5 / 10$ & $8 / 13$ & 19 & 19 & $10 / 13$ & $10 / 13$ & $10,2 \mathrm{ft}$. & $10,2 \mathrm{ft}$. & $10 / 13$ & $10 / 13$ \\
\hline $\begin{array}{l}5 \text { and } \\
\text { Marine }\end{array}$ & 38 & 49 & $20 / 13+5^{b, c}$ & $20 / 13+5^{b, d}$ & $13 / 17$ & $13 / 17$ & $30^{f}$ & $30^{f}$ & $10 / 13$ & $15 / 19$ & $10,2 \mathrm{ft}$. & $10,2 \mathrm{ft}$. & $10 / 13$ & $15 / 19$ \\
\hline 6 & 49 & 49 & $20 / 13+5^{b, c}$ & $20+5 / 13+10^{b, d}$ & $15 / 19$ & $15 / 20$ & $30^{f}$ & $30^{f}$ & $15 / 19$ & $15 / 19$ & $10,4 \mathrm{ft}$. & $10,4 \mathrm{ft}$. & $10 / 13$ & $15 / 19$ \\
\hline 7 and 8 & 49 & 49 & 21 & $20+5 / 13+10^{b, d}$ & $19 / 21$ & $19 / 21$ & $38^{f}$ & $38^{f}$ & $15 / 19$ & $15 / 19$ & $10,4 \mathrm{ft}$. & $10,4 \mathrm{ft}$. & $10 / 13$ & $15 / 19$ \\
\hline $\begin{array}{l}\text { Source: } 20 \\
\text { a. R-value } \\
\text { insulati } \\
\text { b. The firs } \\
\text { insulati } \\
\text { c. If struct } \\
\text { more th } \\
\text { d. If struct } \\
\text { structur } \\
\text { e. The sec } \\
\text { f. Or insul } \\
\text { g. "15/19" } \\
\text { be pern } \\
\text { home. " } \\
\text { h. Baseme } \\
\text { i. R-5 sha } \\
\text { through }\end{array}$ & $\begin{array}{l}9 \text { and } 2012 \\
\text { are minimt } \\
\text { i shall not } \\
\text { value is car } \\
\text { ior insulat } \\
\text { ral sheathir } \\
\text { n } 25 \text { percer } \\
\text { al sheathir } \\
\text { I sheathing } \\
\text { nd R-value } \\
\text { tion suffici } \\
\text { leans R-15 } \\
\text { tted to be } \\
\text { D/13" mear } \\
t \text { wall insul } \\
\text { be added } \\
3 \text { for heate }\end{array}$ & $\begin{array}{l}\text { IECC Ta } \\
\text { ms. Whe } \\
\text { be less th } \\
\text { jity insul } \\
\text { ed siding } \\
\text { g covers } \\
\text { it of exte } \\
\text { g covers } \\
\text { is used } \\
\text { applies } \\
\text { ent to fill } \\
\text { continuo } \\
\text { met with } \\
\text { s-10 cc } \\
\text { ation is r } \\
\text { to the rec } \\
\text { d slabs. }\end{array}$ & $\begin{array}{l}\text { les } 402.11 \\
\text { n insulation is in } \\
\text { an the R-value s } \\
\text { ton, the secono } \\
25 \text { percent or les } \\
\text { ior, structural sh } \\
40 \% \text { or less of } t \\
\text { to maintain a c } \\
\text { hen more than } \\
\text { the framing cavi } \\
\text { is insulated shea } \\
\text { R-13 cavity insul } \\
\text { ntinuous insulat } \\
\text { bt required in w } \\
\text { uired slab edge }\end{array}$ & $\begin{array}{l}\text { nstalled in a cavity } \\
\text { specified in the tabl } \\
\text { d value is continuou } \\
\text { ss of the exterior, in } \\
\text { eathing shall be sur } \\
\text { the exterior, continu } \\
\text { consistent total she } \\
\text { half the insulation } \\
\text { vity, R-19 minimum. } \\
\text { athing on the interi } \\
\text { lation on the interic } \\
\text { ted sheathing on th } \\
\text { varm-humid locatio } \\
\text { R-values for heate }\end{array}$ & $\begin{array}{l}\text { which is I } \\
\text { Is insulati } \\
\text { sulating s } \\
\text { oplement } \\
\text { ous insul } \\
\text { athing thi } \\
\text { is on the } \\
\text { or or exte } \\
\text { r of the } \\
\text { e interior } \\
\text { ns as defil } \\
\text { d slabs. Ir }\end{array}$ & $\begin{array}{l}\text { ess than th } \\
\text { on or insu } \\
\text { heathing is } \\
\text { d with ins } \\
\text { tion R-va } \\
\text { ckness } \\
\text { nterior of } \\
\text { rior of the } \\
\text { asement } \\
\text { or exterio } \\
\text { ned by } 20 \\
\text { sulation c }\end{array}$ & $\begin{array}{l}\text { e labeled } \\
\text { ated sidin } \\
\text { not requi } \\
\text { ulated she } \\
\text { ue shall b } \\
\text { he mass } \\
\text { home or } \\
\text { vall plus } F \\
\text { of the ho } \\
9 \text { and } 20 \\
\text { epth shall }\end{array}$ & $\begin{array}{l}\text { design thi } \\
\text {, so "13+s } \\
\text { thing of } \\
\text { permitte } \\
\text { yall. }\end{array}$ & $\begin{array}{l}\text { ckness of } \\
\text { " means } \mathrm{F} \\
\text { structural } \\
\text { at least R-2 } \\
\text { ed to be re }\end{array}$ & $\begin{array}{l}\text { he insulat } \\
-13 \text { cavity } \\
\text { heathing } \\
\text { uced by r }\end{array}$ & $\begin{array}{l}\text { on, the insta } \\
\text { insulation p } \\
\text { s used. If str } \\
\text { o more that }\end{array}$ & $\begin{array}{l}\text { alled R-valu } \\
\text { lus R-5 cont } \\
\text { uctural shea } \\
\text { R-3 in the }\end{array}$ & $\begin{array}{l}\text { of the } \\
\text { inuous } \\
\text { thing cover } \\
\text { ocations }\end{array}$ & \\
\hline
\end{tabular}




\section{Training}

No resources available.

\section{Architectural CAD Files}

None available. 


\section{Compliance}

Local building codes have specific requirements such as the R-value of insulation, fire and combustion requirements, radon mitigation requirements, flood prevention requirements, and requirements for a pest control inspection strip at the top and/or the bottom of the foundation wall. Begin by checking with local authorities to ensure that all materials and work will comply with local code requirements.

2012 IECC

The following is a guide for insulation requirements by location for 2012 IECC with a comparison to 2009 IECC included.

Table 1. Minimum Insulation Levels for New Homes Required by the 2009 and 2012 IECC, Adapted from 2012 IECC Table R402.1.1 and 2009 IECC Table 402.1.1. (PNNL and ORNL 2012).

Table 2.1. Minimum Insulation Levels ${ }^{\mathrm{a}}$ for New Homes as Required by the 2009 and 2012 International Energy Conservation Code.

\begin{tabular}{|c|c|c|c|c|c|c|c|c|c|c|c|c|c|c|}
\hline \multirow{2}{*}{$\begin{array}{l}\text { Climate } \\
\text { Zone }\end{array}$} & \multicolumn{2}{|c|}{$\begin{array}{l}\text { Ceiling } \\
\text { R-Value }\end{array}$} & \multicolumn{2}{|c|}{$\begin{array}{l}\text { Wood Frame Wall } \\
\text { R-Value }\end{array}$} & \multicolumn{2}{|c|}{$\begin{array}{l}\text { Mass Wall }^{c} \\
\text { R-Value }\end{array}$} & \multicolumn{2}{|c|}{$\begin{array}{c}\text { Floor } \\
\text { R-Value }^{\mathrm{d}}\end{array}$} & \multicolumn{2}{|c|}{$\begin{array}{c}\text { Basement } \\
\text { Wall }^{\mathrm{e}} \mathrm{R}-\text { Value }\end{array}$} & \multicolumn{2}{|c|}{$\begin{array}{l}\text { Slab R-Value }{ }^{f} \\
\text { and Depth }\end{array}$} & \multicolumn{2}{|c|}{$\begin{array}{l}\text { Crawlspace }^{\mathrm{g}} \\
\text { Wall R-Value }\end{array}$} \\
\hline & $\begin{array}{l}2009 \\
\text { IECC }\end{array}$ & $\begin{array}{l}2012 \\
\text { IECC }\end{array}$ & $\begin{array}{l}2009 \\
\text { IECC }\end{array}$ & $\begin{array}{l}2012 \\
\text { IECC }\end{array}$ & $\begin{array}{l}2009 \\
\text { IECC }\end{array}$ & $\begin{array}{l}2012 \\
\text { IECC }\end{array}$ & $\begin{array}{l}2009 \\
\text { IECC }\end{array}$ & $\begin{array}{l}2012 \\
\text { IECC }\end{array}$ & $\begin{array}{l}2009 \\
\text { IECC }\end{array}$ & $\begin{array}{l}2012 \\
\text { IECC }\end{array}$ & $\begin{array}{l}2009 \\
\text { IECC }\end{array}$ & $\begin{array}{l}2012 \\
\text { IECC }\end{array}$ & $\begin{array}{l}2009 \\
\text { IECC }\end{array}$ & $\begin{array}{l}2012 \\
\text { IECC }\end{array}$ \\
\hline 1 & 30 & 30 & 13 & 13 & $3 / 4$ & $3 / 4$ & 13 & 13 & 0 & 0 & 0 & 0 & 0 & 0 \\
\hline 2 & 30 & 38 & 13 & 13 & $4 / 6$ & $4 / 6$ & 13 & 13 & 0 & 0 & 0 & 0 & 0 & 0 \\
\hline 3 & 30 & 38 & 13 & $20 / 13+5^{b, d}$ & $5 / 5$ & $8 / 13$ & 19 & 19 & $5 / 13^{h}$ & $5 / 13^{h}$ & 0 & 0 & $5 / 13$ & $5 / 13$ \\
\hline $\begin{array}{c}4 \text { except } \\
\text { Marine }\end{array}$ & 38 & 49 & 13 & $20 / 13+5^{b, d}$ & $5 / 10$ & $8 / 13$ & 19 & 19 & $10 / 13$ & $10 / 13$ & $10,2 \mathrm{ft}$. & $10,2 \mathrm{ft}$. & $10 / 13$ & $10 / 13$ \\
\hline $\begin{array}{l}5 \text { and } \\
\text { Marine }\end{array}$ & 38 & 49 & $20 / 13+5^{b, c}$ & $20 / 13+5^{b, d}$ & $13 / 17$ & $13 / 17$ & $30^{f}$ & $30^{f}$ & $10 / 13$ & $15 / 19$ & $10,2 \mathrm{ft}$. & $10,2 \mathrm{ft}$. & $10 / 13$ & $15 / 19$ \\
\hline 6 & 49 & 49 & $20 / 13+5^{b, c}$ & $20+5 / 13+10^{b, d}$ & $15 / 19$ & $15 / 20$ & $30^{f}$ & $30^{f}$ & $15 / 19$ & $15 / 19$ & $10,4 \mathrm{ft}$. & $10,4 \mathrm{ft}$. & $10 / 13$ & $15 / 19$ \\
\hline 7 and 8 & 49 & 49 & 21 & $20+5 / 13+10^{b, d}$ & $19 / 21$ & $19 / 21$ & $38^{f}$ & $38^{f}$ & $15 / 19$ & $15 / 19$ & $10,4 \mathrm{ft}$. & $10,4 \mathrm{ft}$. & $10 / 13$ & $15 / 19$ \\
\hline
\end{tabular}

Source: 2009 and 2012 IECC Tables 402.1.

a. R-values are minimums. When insulation is installed in a cavity which is less than the labeled design thickness of the insulation, the installed R-value of the insulation shall not be less than the R-value specified in the table

b. The first value is cavity insulation, the second value is continuous insulation or insulated siding, so "13+5" means R-13 cavity insulation plus R- 5 continuous insulation or insulated siding.

c. If structural sheathing covers 25 percent or less of the exterior, insulating sheathing is not required where structural sheathing is used. If structural sheathing covers more than 25 percent of exterior, structural sheathing shall be supplemented with insulated sheathing of at least R-2.

d. If structural sheathing covers $40 \%$ or less of the exterior, continuous insulation R-value shall be permitted to be reduced by no more than R-3 in the locations where structural sheathing is used - to maintain a consistent total sheathing thickness

e. The second R-value applies when more than half the insulation is on the interior of the mass wall.

f. Or insulation sufficient to fill the framing cavity, R-19 minimum.

g. "15/19" means R-15 continuous insulated sheathing on the interior or exterior of the home or R-19 cavity insulation at the interior of the basement wall. "15/19" shall be permitted to be met with R-13 cavity insulation on the interior of the basement wall plus R-5 continuous insulated sheathing on the interior or exterior of the home "10/13" means R-10 continuous insulated sheathing on the interior or exterior of the home or R-13 cavity insulation at the interior of the basement wall.

h. Basement wall insulation is not required in warm-humid locations as defined by 2009 and 2012 Figure 301.1 and Table 301.1.

. R-5 shall be added to the required slab edge R-values for heated slabs. Insulation depth shall be the depth of the footing or 2 feet, whichever is less in Zones 1 through 3 for heated slabs. 


\section{More Info}

\section{Case Study}

PNNL. 2014. Building America Case Study Technology Solutions for New and Existing Homes: Exterior-Side Foundation Insulation for Existing Homes. Prepared by the Pacific Northwest National Laboratory for the U.S. Department of Energy Building America Program.

Climate Zone: All

Case Study Type: Measure Specific

Construction Type: Existing

\section{References}

PNNL and ORNL 2012. Building America Best Practices Series: Energy Renovations:

Insulation - A Guide for Contractors to Share with Homeowners. Prepared by the Pacific Northwest National Laboratory and Oak Ridge National Laboratory.

http://apps1.eere.energy.gov/buildings/publications/pdfs/building_america/insulation_guide.pdf Accessed May 20, 2014. 
